\title{
Summary of Radionuclide Air Emissions from Department of Energy Facilities for CY 1993
}

April 1995

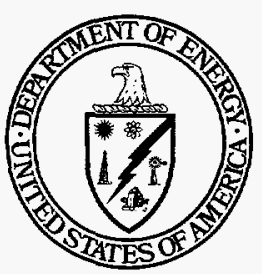

U.S. Department of Energy

Assistant Secretary for Environment, Safety, and Health Office of Environmental Policy and Assistance Washington, DC 20585 



\section{DISCLAIMER}

This report was prepared as an account of work sponsored by an agency of the United States Government. Neither the United States Government nor any agency thereof, nor any of their employees, make any warranty, express or implied, or assumes any legal liability or responsibility for the accuracy, completeness, or usefulness of any information, apparatus, product, or process disclosed, or represents that its use would not infringe privately owned rights. Reference herein to any specific commercial product, process, or service by trade name, trademark, manufacturer, or otherwise does not necessarily constitute or imply its endorsement, recommendation, or favoring by the United States Government or any agency thereof. The views and opinions of authors expressed herein do not necessarily state or reflect those of the United States Government or any agency thereof. 


\section{DISCLAIMER}

Portions of this document may be illegible in electronic image products. Images are produced from the best available original document. 


\section{EXECUTIVE SUMMARY}

Radionuclide air emission reports for 1993 were submitted to the Environmental Protection Agency (EPA) from thirty-seven DOE operational sites and eight non-operational remedial action sites. The reports for calendar year 1993 were submitted to EPA by June 30, 1994. Radionuclide emissions to the atmosphere from normal operations at DOE facilities were approximately 230,000 curies (Ci) $\left(8.5 \times 10^{3} \mathrm{TBq}^{1}\right)$ during 1993 .

All DOE sites demonstrated compliance with the $10 \mathrm{mrem} / \mathrm{yr} / 0.1$ $\mathrm{mSv} / \mathrm{Yr}$ ) effective dose equivalent (EDE) standard of $40 \mathrm{CFR} 61$, Subpart $H$ for 1993. Over $85 \%$ of the DOE operating facilities subject to the radionuclide NESHAPs reported doses to the maximally exposed individual (MEI) offsite that were less than $1 \%$ of the standard. Doses to the MEI at each DOE facility were estimated using methods and computer codes specified by EPA. CAP-88 or CAP88-PC dose assessment modeling were used by $90 \%$ of the DOE sites to demonstrate compliance with the dose standard. The highest estimated dose from normal operations was about $50 \%$ of the standard at one site, with the next highest dose being less than $20 \%$ of the standard. Four sites reported doses between $1 \%$ and $10 \%$ of the standard. Radionuclide releases (excluding radon) from unplanned releases resulted in individual doses that were less than 0.1 mrem $(0.001 \mathrm{mSv})$ during 1993 .

Emissions from diffuse or non-point sources were significant when compared to point source emissions at ten DOE sites although fourteen other sites reported diffuse source emissions as well. The highest dose at any one site from diffuse source emissions was $0.22 \mathrm{mrem} / \mathrm{Yr}(0.0022 \mathrm{mSv} / \mathrm{Yr})$. The diffuse source emissions second

1 Terabecquerel $(\mathrm{TBq})=10^{12} \mathrm{~Bq}=10^{12}$ disintegrations per

1 curie $=0.037 \mathrm{TBq}$ 
are only about one percent of the total radionuclide release to the atmosphere from DOE facilities during 1993.

Radon emissions were reported for radon-222 and radon-220 from six DOE sites. Radon-220 emissions, which are not subject to the radionuclide NESHAPs limits, were a significant contributor to the offsite dose at two DOE sites. However, the reported doses for radon-220 were less than a few percent of the NESHAPs 10 mrem/yr (0.1 mSv/yr) standard.

The total collective dose within $80 \mathrm{~km}$ (50 miles) of DOE facilities was estimated to be about 95 person-rem $(0.95$ personSv). This dose would not be expected to result in any observable health effects to the exposed population. By comparison, collective dose estimates from natural background radiation to the same population group are several orders of magnitude higher.

DOE has twelve sites that are considered major sources of radionuclide emissions subject to the continuous monitoring requirements of subpart $\mathrm{H}$. Of these twelve DOE sites, six are in full compliance with the EPA continuous monitoring requirements. Two DOE sites have signed individual Federal Facilities Compliance Agreements (FFCA) with their respective EPA regional office and are in the process of completing upgrades. Two sites are actively negotiating separate FFCA's with the appropriate EPA regional office. One site is completing upgrades under an informal agreement with its EPA regional office and another site was under a compliance order issued by its EPA regional office that has since expired. The DOE site subject to the compliance order has an agreement with EPA to use an EPA-approved alternate method to satisfy the concerns addressed by the compliance order.

All other DOE sites are considered minor sources and either have completed or are at various stages of completing the protocol for periodic confirmatory measurements (PCM) at their sites. These 
measurement protocols are being developed in coordination with EPA regional offices and are being submitted to the EPA regional offices as a means of demonstrating compliance with the PCM requirements. 



\section{CONTENTS}

EXECUTIVE SUMMARY $\ldots \ldots \ldots \ldots \ldots \ldots \ldots \ldots \ldots \ldots \ldots \ldots \ldots \ldots$

TABLE OF CONTENTS ......................... iv

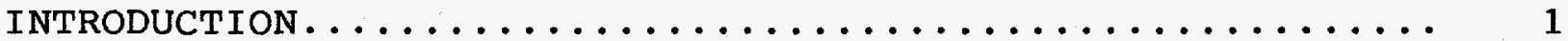

SECTION 1. Compliance with the NESHAPs Subpart H Dose standard

1.1 REgULATORY REQUIREMENTS.................... 3

1.2 RADIONUCLIDE EMISSIONS TO THE ATMOSPHERE DURING NORMAL

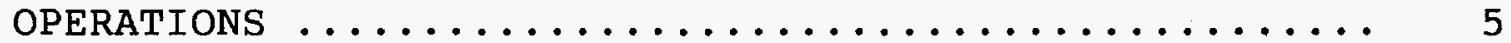

1.3 DOSIMETRY MODELS AND CODES .................. 6

1.4 STATUS OF COMPLIANCE WITH THE SUBPART H STANDARD..... 8

1.5 EMISSIONS FROM DIFFUSE OR NON-POINT SOURCES (OTHER

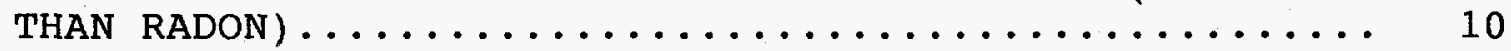

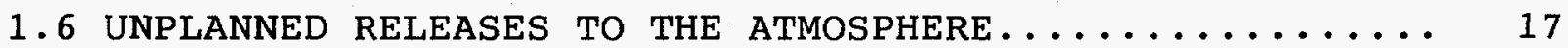

SECTION 2. Supplemental Information

2.1 RADON EMISSIONS $\ldots \ldots \ldots \ldots \ldots \ldots \ldots \ldots \ldots \ldots \ldots \ldots \ldots \ldots \ldots \ldots$

2.2 COLlective dose estimates....................... 24

2.3 STATUS OF COMPLIANCE WITH EMISSION MONITORING REQUIREMENTS IN 40 CFR PART 61 , SUBPART H.......... 25

Section 3. SUMMARY OF DOE/EPA ACTIVITIES AND INITIATIVES

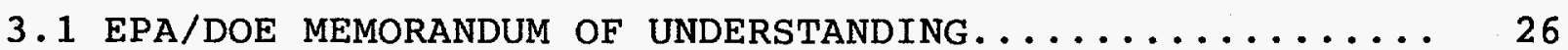

3.2 EPA APPROVAL OF ALTERNATE REFERENCE METHOD.......... 27

3.3 EPA REPORT ON DIFFUSE SOURCE ESTIMATION............ 28

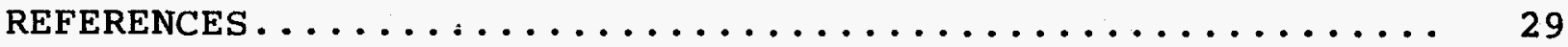

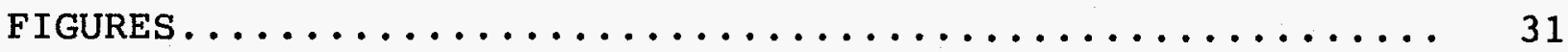

TABLES................................. 32 


\section{INTRODUCTION}

Facilities owned or operated by the U. S. Department of Energy (DOE) handle and process radioactive materials in conjunction with their research, nuclear materials production, remediation, and waste disposal activities. During normal operations, some of these facilities have the potential to release small quantities of radionuclides to the environment. Radionuclide emissions to the atmosphere from DOE facilities are regulated by the $U$. $S$. Environmental Protection Agency (EPA) under the authority of Section 112 of the Clean Air Act. Subpart H of 40 CFR Part 61 of the National Emission Standards for Hazardous Air Pollutants (NESHAPs) sets standards for public exposure to airborne radioactive materials (other than radon) released by DOE facilities. DOE radon emissions are regulated by NESHAPs in Subparts $Q$ and $T$. Subparts $Q$ and $T$ apply specifically to DOE storage and disposal facilities for radium-containing material. Airborne radionuclide emissions are also regulated by the Department of Energy under the authority provided by the Atomic Energy Act of 1954, as amended, and the Department of Energy Organization Act of 1977, as amended. This report summarizes air emissions subject to the EPA requirements and demonstrates that DOE facilities are in compliance with the required dose limits.

One requirement of 40 CFR Part 61, Subpart $\mathrm{H}$ (Section 61.94) is that DOE facilities submit annual reports to their respective EPA regional offices and to EPA headquarters describing their activities during the previous calendar year, including estimates of atmospheric radionuclide emissions and the resulting dose to the maximally exposed individual (MEI). The site reports describing 1993 emissions and dose levels were due to EPA by June 30, 1994. This report summarizes the information in the DOE air emission reports submitted to EPA for calendar year 1993. An overview of DOE facility compliance with the NESHAPs subpart $H$ dose standard is provided in section 1 . In addition to the 
required compliance information, supplemental information on air emissions is discussed in section 2 .

Table 1 lists the DOE sites covered by this report, including the associated acronyms used in the figures, tables, and text. The sites are grouped according to the DOE operations office that manages their activities. Figure 1 shows the general location of each site relative to the EPA region within which it is located. The DOE facilities at KCP, AMES, and RMI are included in Table 1 and Figure 1 , however these facilities had no radionuclide emissions during 1993 and are, therefore, omitted from subsequent tables and figures. Air emission reports for 1993 were received from thirty-seven DOE research or production sites and from eight DOE storage or disposal sites that currently have no ongoing operations other than remedial actions.

In addition to the individual DOE facility air emissions reports provided to EPA, and the annual air emissions summary report, DOE requires each site to prepare an Annual Site Environmental Report (ASER) . These reports provide information on radionuclide emissions from DOE sites due to all pathways, including air.

In the NESHAPs annual reports, airborne emissions were assessed primarily for point sources, however other sources were evaluated including unplanned releases, emissions from diffuse and unmonitored sources, and radon. Emissions from non-point (diffuse) sources were generally several orders of magnitude lower than emissions resulting from routine point-source operations, except at seven sites where production operations have been suspended.

Although there is no regulatory standard for collective dose and its estimation is not required by the radionuclide NESHAPs, DOE directives require the calculation of collective dose to support DOE oversight of its activities and the application of its ALARA 
policy. Therefore, collective dose estimates for each site are provided in this report for information purposes only.

SECTION 1. COMPLIANCE WITH THE NESHAPS SUBPART H DOSE STANDARD

This section of the report covers information related to radiological impacts on the public resulting from operations at DOE facilities. Regulatory requirements for reporting by DOE facilities are discussed, as are the models used to prepare the dose estimates. The quantities of radionuclides released into the atmosphere from DOE facilities and the estimated doses to the MEI, are summarized.

\subsection{Regulatory Requirements}

On December 15, 1989, EPA promulgated radionuclide emission standards as part of the National Emission Standards for Hazardous Air Pollutants (NESHAPs), which became effective during calendar year 1990 . The radionuclide emissions (other than radon) from DOE operations are regulated under subpart $H$ of 40 CFR Part 61. The radon emissions from DOE storage and disposal facilities are regulated under 40 CFR Part 61 , Subpart $Q$ and from uranium mill tailings disposal sites under 40 CFR Part 61 , Subpart T.

The dosimetry system of 40 CFR Part 61, Subpart $H$ requires the use of the effective dose equivalent (EDE) for evaluation of public exposure, as recommended by the International Commission on Radiological protection in its Publication 26 (ICRP 1977). The EDE is the sum of the annual dose resulting from external exposure and the 50-year committed EDE resulting from internal exposure to radionuclides inhaled or ingested during the year. Internal dose is calculated by combining doses to specific 
organs, with each dose weighted by a factor related to the risk of radiation-induced health effects in that organ. The dose standard requires that annual doses from radionuclide emissions to the air at DOE facilities (excluding radon) not exceed a 10 mrem ( $0.1 \mathrm{mSv}$ ) EDE to the MEI.

DOE facilities are required by Section 61.94 of 40 CFR Part 61 to provide EPA with an annual report describing radionuclide emissions and calculated doses to the public. Each report must include a description of the physical site, the types of radionuclides handled there, and any processes involving radionuclides that are conducted at the facility. The report must also include a list of all stacks or vents that have a potential for airborne radionuclide emission, the type and efficiency of effluent control systems used at each release point, and the distance to the nearest offsite receptors. DOE has agreed to identify its diffuse or non-point sources and include the results of their emission estimates as part of this report.

In order to demonstrate compliance with the protective requirements of $40 \mathrm{CFR}$ Part 61 , each site must estimate the total quantity of radionuclides released (for both point and non-point sources) from its facilities during the calendar year, and evaluate the impact of those emissions on the MEI. In general, the point source emissions are reported separately and used to document compliance with the standard. Since EPA does not specify in the regulations acceptable methods or procedures for assessing the diffuse or non-point source emissions, DOE has utilized its own methods and approaches to evaluate the emissions from these sources. The diffuse source results are generally reported separately from the point-source results and the two results compared as a means of demonstrating that the 10 mrem/year $(0.1 \mathrm{mSv} / \mathrm{yr})$ dose standard is not exceeded when all sources of emissions are considered. Some sites have combined 
the results and reported the sum in cases where either one or the other dominates the overall result.

DOE prepared this overview report to provide EPA and other interested parties with a summary of the information reported in individual site reports. This overview report is not required by the regulations and is provided with the intent of consolidating and clarifying information and data reported by the individual DOE sites.

\subsection{Radionuclide Emissions to the Atmosphere During Normal operations}

For the purposes of this report, emissions resulting from normal operations are generally defined as releases from facility stacks. Certain releases from diffuse (non-point) sources have resulted from normal, routine activities at a site and are included in the site dose assessment. Routine production operations for many DOE sites have ceased such as those associated with the nuclear weapons production and testing. In some of these cases, emissions from non-point sources can exceed the site emissions from stacks. Point-source radionuclide emissions to the atmosphere resulting from normal operations during 1993 are summarized in Table 2, and are divided into four categories - tritium, noble gases, transuranics, and all other radionuclides. Detailed site-specific information on releases by radionuclide is contained in the NESHAPs air emission reports for each individual site. Approximately $230,000 \mathrm{Ci}\left(8.5 \times 10^{3} \mathrm{TBq}\right)$ of radionuclides were released to the atmosphere from normal operations at DOE facilities during 1993. This is about an 8\% reduction in radioactivity released to the atmosphere from the previous year. The majority of the total radioactivity released to the atmosphere in 1993 was from tritium (85\%). Tritium is a prominent release component with more than two-thirds of the DOE 
sites reporting some level of tritium release. The emission of transuranic isotopes, which present more of a radiation hazard than tritium, was at a level of less than $0.01 \mathrm{Ci}\left(3.7 \times 10^{-4}\right.$ TBq).

Emissions from non-point sources such as waste disposal sites, contaminated soil areas, or inactive facilities under the Formerly Utilized Sites Remedial Action Program (FUSRAP) are discussed separately in section 1.5 of this report.

\subsection{Dosimetry Models and Codes}

The dosimetry model is implemented through the use of computer software packages specified by the regulations and is used by DOE sites to demonstrate compliance with the dose standard. The EPA approved code packages include CAP-88, CAP88-PC, AIRDOS-PC, and COMPLY. Approval of alternate methods for demonstrating compliance with the dose standard may be requested from EPA on a case-by-case basis. The models used by individual DOE sites to demonstrate compliance with the standard for 1993 are indicated in Table 3 .

The CAP-88 code package (Beres 1990) implements a steady-state gaussian plume atmospheric dispersion model, and comes with a set of radionuclide-specific data that generally corresponds to the data used in the internal dosimetry models described in ICRP Publication 30 (ICRP 1979-1982). It provides the most flexibility of the four EPA approved codes in terms of ability to input site-specific data, however it is also the most difficult and expensive of the codes to operate because it requires a mainframe computer system. This code was used by twelve of the thirty-seven reporting DOE sites to demonstrate compliance with the NESHAP requirements. 
A personal computer version of the CAP-88 code, developed by EPA (Parks 1992) with DOE funding, was released in March 1992 under the name CAP88-PC. This code provides most of the features of the CAP-88 code in a personal computer format. It retains the complete radionuclide library and the capability to perform collective dose calculations. CAP88-PC allows more DOE facilities to have access to CAP- 88 modeling. The code is easily installed on any personal computer containing a math coprocessor and at least $3.5 \mathrm{Mb}$ of free hard disc capacity. CAP88-PC was used by twenty DOE sites to assess the dose to the public and for demonstrating compliance with the dose standard for calendar year 1993.

Another code, AIRDOS-PC, is available but, because of its limited radionuclide library, which consists of about 40 isotopes compared to several hundred in CAP-88, and the lack of a capability to estimate collective dose, DOE sites did not utilize AIRDOS-PC for demonstrating compliance with the dose standard in 1993 .

The COMPLY code (EPA 1989C) is a screening model consisting of four levels, each of which requires increasingly detailed sitespecific data to produce a more realistic (and less conservative) dose estimate. COMPLY is useful for relatively small sites because it does not require extensive site-specific data. It has a large radionuclide library comparable to that for CAP-88, and may be used for situations where the receptor is located nearer the site than is appropriate for the other codes. However, lower screening levels of COMPLY will provide more conservative results. Four DOE sites used COMPLY to estimate doses for their 1993 air emissions reports. Of the sites that used this code, three reported results at screening level 4 (the least conservative option using a maximum of site-specific data) and one site reported results at screening level 2 (a more conservative value). Two of the sites (EML \& LBL) used COMPLY 
because of the close proximity of the radionuclide sources with respect to the public dose receptors. The other two sites (MIT \& PPPL) utilized the code because of the unavailability of some of the input data required to run CAP88-PC.

The models used in demonstrating NESHAP compliance contain varying degrees of conservatism. The degree of conservatism varies with the approach, the code used, and specific conditions at the site to which it is applied. In general, the more simplistic models utilize fewer site-specific parameters as input and produce more conservative results. Because doses from radionuclide emissions at many DOE facilities are very low, the degree of conservatism in the resulting dose estimates does not significantly impact the ability of sites to demonstrate compliance with the dose standard. However, with $90 \%$ of the DOE sites using CAP-88 and CAP88-PC, some internal consistency is established between results reported by different facilities.

\subsection{Status of Compliance with the subpart $\mathrm{H}$ Standard}

For calendar year 1993, all DOE facilities demonstrated compliance with the $10 \mathrm{mrem} / \mathrm{yr}(0.1 \mathrm{mSv} / \mathrm{yr})$ EDE dose limit specified by the Clean Air Act under 40 CFR Part 61, subpart $H$. The doses reported by DOE facilities for compliance purposes are primarily based on point-source emissions. The point-source assessments are conducted in accordance with the EPA approved methods and procedures specified in 40 CFR Part 61 , subpart $H$.

Table 3 lists the calculated doses based in general on point source assessments. The doses are calculated from exposures to the MEI from atmospheric radionuclide emissions at DOE sites during calendar year 1993. The EPA-approved computer codes used to produce the dose estimate for each site and the approximate distance to the receptor for each site are also indicated in 
Table 3. Figure 2 shows graphically how the dose at each DOE site compares with the $10 \mathrm{mrem} / \mathrm{Yr}(0.1 \mathrm{mSv} / \mathrm{Yr})$ standard in $40 \mathrm{CFR}$ Part 61 , Subpart $H$. Estimates of dose ranged from about $1.0 \times$ $10^{-6} \mathrm{mrem} / \mathrm{yr}\left(1.0 \times 10^{-8} \mathrm{mSv} / \mathrm{yr}\right)$ to $5.6 \mathrm{mrem} / \mathrm{yr}(0.056 \mathrm{mSv} / \mathrm{yr})$.

Of the thirty-seven operational DOE sites subject to 40 CFR Part 61, Subpart $H, 85 \%$ of the sites reported doses below $0.1 \mathrm{mrem} / \mathrm{Yr}$ $(0.001 \mathrm{mSv} / \mathrm{yr})$ or $1 \%$ of the standard. The highest estimated dose from normal operations was about $50 \%$ of the standard at one site (LANL), with the next highest dose (ORR) being less than $20 \%$ of the standard. Four sites (BNL, LBL, PORT, \& SRS) reported doses between $1 \%$ and $10 \%$ of the standard. Most of the reported dose estimates for 1993 did not change substantially from 1992 except for those reported by GJPO, NTS, INEL, and MIT. As a result of operations for 1993, GJPO and NTS had significantly reduced dose values and INEL and MIT had significantly increased radionuclide emissions to the atmosphere. A number of sites have operations that are suspended, either temporarily or permanently, and have reported doses in recent years that are significantly lower than those reported in prior years when the facilities were in full operation.

Diffuse sources of radionuclide emissions (other than radon) generally result from secondary processes such as the resuspension of contaminated soil and contribute only a small fraction to the facility emissions. Because the 1993 reported results demonstrate that radionuclide emissions from DOE facilities are generally several orders of magnitude below the standard, the inclusion of non-point source emissions in dose assessments does not impact DOE facility compliance with the 10 mrem/yr ( $0.1 \mathrm{mSv} / \mathrm{yr})$ standard. However, the diffuse emissions, although small, may be the primary contributor to emissions from inactive DOE sites. 


\subsection{Emissions from Diffuse or Non-Point Sources (Other than Radon)}

The radionuclide emission requirements in Subpart $H$ of 40 CFR Part 61 , do not specifically address non-point or diffuse source emissions such as resuspension of radionuclides from contaminated surfaces or the atmospheric emissions of radionuclides from contaminated ponds and lagoons. Because the primary sources of exposure for operating DOE facilities are emissions from stacks and vents, the regulations and associated guidance emphasize point sources. DOE has been evaluating radionuclide emissions associated with non-point or diffuse sources and has provided this data along with the dose assessment results as part of the 1993 air emissions report. Because the diffuse source and point source estimates of dose are carried out independently using very different methods, the calculated doses may not be to the same individuals or locations offsite. Therfore, these doses are not necessarily additive.

Twenty-one DOE sites reported doses from non-point (diffuse) source emissions in 1993. Eight of these sites (BNL, LANL, LBL, NTS, PANX, RFP, SNLA, \& SRS) included part or all of the diffuse source emission estimates in the total dose that was reported for NESHAP compliance. The quantitative estimates of non-point or diffuse source emissions from DOE sites are presented in Table 4, and the dose impacts from these emissions are listed in Table 6 . Combined radionuclide emissions to the atmosphere in 1993 from all diffuse sources identified at DOE amounted to approximately $2400 \mathrm{Ci}$ ( $88 \mathrm{TBq}$ ). This amount is generally comparable to release levels in past years. The 1993 emissions from diffuse sources amount to about one percent of the total DOE emissions from point sources. The maximum potential dose to an offsite individual from diffuse source emissions at any site is less than 0.22 mrem $(0.0022 \mathrm{mSv})$, except at LANL where the dose from diffuse sources is 1.1 mrem $(0.011 \mathrm{mSv})$. 
The methods used to generate release estimates for diffuse sources varied with the site. These methods often utilized very conservative assumptions when measured data were not available. The results are further complicated by the variety of diffuse sources at DOE facilities, ranging from contaminated soil areas to evaporation ponds used for temporary storage of radioactive liquid wastes. DOE is continuing to work on improving the identification and characterization of non-point or diffuse sources at its facilities. Some methodologies have been developed by EPA and are being evaluated by DOE for use in assessing the non-point source emissions. DOE will continue to provide information and data on diffuse source emissions to EPA. DOE will utilize environmental surveillance measurements, where available, for verification purposes.

Of the twenty-one DOE sites reporting diffuse source emissions results, ten (GJPO, MLM, PANX, FEMP, WVDP, NTS, LLNL-300, SSFLRI, HANF, and RFP) had diffuse source emissions as the primary release. Six of these sites (MLM, FEMP, LANL-300, RI, HANF, and RFP) no longer operate according to their historic mission within the Department and are conducting activities associated with environmental cleanup and restoration. PANX continues to monitor its environmental tritium releases that resulted from an accident in 1989. NTS operates with large area sources being the primary contributor to the offsite dose and therefore has used the results of diffuse source dose assessments to demonstrate compliance with the subpart $H$ standard. WVDP operates storage and disposal sites that are treated as diffuse sources in their dose assessments. GJPO is active and has at least one significant point source but also has emissions from remediation of its tailings piles as part of normal operations. A discussion of the ten sites reporting significant diffuse source emissions follows. 
Mound has low-level diffuse emissions of $\mathrm{Pu}-238$ and $\mathrm{Pu}-239$ due to resuspension from D\&D activities. Environmental measurements were used to obtain the resulting value of $1.1 \times 10^{-4} \mathrm{Ci}$ (4.1 $\mathrm{x}$ $10^{6} \mathrm{~Bq}$ ) being released from the Mound Site. Doses from diffuse sources were estimated by subtracting modeled point source doses from estimates of doses based on environmental measurements. The dose associated with measured plutonium stack emissions as predicted from CAP-88 is significantly smaller than the dose estimated from environmental plutonium air sampling data. It was assumed that the balance included resuspension of $\mathrm{Pu}$ deposits. The estimated offsite committed EDE to the MEI offsite was 0.22 mrem $(0.0022 \mathrm{mSv})$ from diffuse sources as compared with 0.04 mrem $\left(4.0 \times 10^{-4} \mathrm{mSv}\right)$ from point sources.

Diffuse sources at Site 300 of LLNL have tritium and uranium as contaminants of potential concern at six locations within the site. Tritium evaporation from landfills, firing table soils, and ground water are sources of tritium emissions to the atmosphere at site 300. Tritium flux from the Pit 7 Complex was calculated from tritium activity data obtained from subsurface soil samples collected at depths from 0.15 to $3 \mathrm{~m}$, and well purge water. Based on its surface area, Well 8 spring contains an estimated $2.4 \times 10^{-3} \mathrm{Ci}\left(89 \times 10^{6} \mathrm{~Bq}\right)$ tritium in the ground water. In addition, Buildings 850,851 , and 802 have tritium emissions. The total estimated dose from all tritium emissions was $1.1 \times 10^{-3} \mathrm{mrem}\left(1.1 \times 10^{-5} \mathrm{mSv}\right)$. Depleted uranium isotopes were also released from diffuse sources, however the airborne particulate sampling did not distinguish between the depleted and naturally occurring uranium. The average concentration in eight samplers was used to represent the concentration at the location of the MEI offsite for site 300. The resultant 1993 dose to the MEI from inhalation of resuspended depleted uranium was estimated to be 0.026 mrem $\left(2.6 \times 10^{-4} \mathrm{mSv}\right)$. 
Diffuse radionuclide sources at the Hanford Site were conservatively assumed to come from the 200 West Area. Principal radionuclides of interest include ${ }^{90} \mathrm{Sr},{ }^{106} \mathrm{Ru},{ }^{129} \mathrm{I},{ }^{137} \mathrm{Cs}, 235$

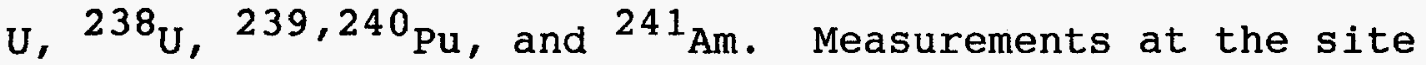
perimeter do not vary significantly from those measured at distant community stations which are unaffected by Hanford effluent. Average release estimates for diffuse sources were calculated using measured air concentrations. This resulted in $1.1 \times 10^{-3} \mathrm{Ci}\left(4.1 \times 10^{7} \mathrm{~Bq}\right)$ of transuranic radionuclides and 1.0 $\mathrm{Ci}\left(3.7 \times 10^{10} \mathrm{~Bq}\right)$ of the other radionuclide types. The mean measurements were used to calculate the EDE to the MEI. The location of the MEI was chosen to represent the highest concentration for environmental measurements, and the nearest station to the MEI determined for the stack releases. The calculated doses at the two stations were 0.049 and $0.028 \mathrm{mrem} / \mathrm{yr}$ $\left(4.9 \times 10^{-4}\right.$ and $\left.2.8 \times 10^{-4} \mathrm{msv} / \mathrm{y}\right)$ respectively. The combined EDE from stack emissions, diffuse and unmonitored sources during 1993 was substantially below the Subpart H $10 \mathrm{mrem} / \mathrm{yr}(0.1$ $\mathrm{mSv} / \mathrm{yr}$ ) standard.

The primary diffuse radiological effluent from the Nevada Test Site (NTS) are noble gases and tritium. The sources of radionuclide emissions are from underground nuclear testing, firing sites, containment and evaporation ponds, and waste management facilities. The noble gases emanate from the ground where underground nuclear testing takes place. No such testing was conducted in 1993. Krypton-85 was detected at all environmental sampling locations on the NTS as it has been in previous years. The total noble gas source term was $160 \mathrm{Ci}$ (5.9 TBq) . Tritium evaporates from containment ponds that hold radiologically contaminated water seeping from the tunnels in Area 12. As the tunnel complexes are being sealed, the discharge is decreasing. Tritiated water also is emanating from the radioactive waste management complex. The total tritium source term for NTS was $0.29 \mathrm{Ci}(0.011 \mathrm{TBq})$ in 1993. Small amounts of 
Pu are also present in surface soil. Air samplers only detect amounts slightly above the minimum detectable concentration of $\mathrm{Pu}-239,240$. CAP-88 was used to back-calculate the total release. The total calculated dose to the MEI offsite from diffuse sources for 1993 was $3.8 \times 10^{-3}$ mrem $\left(3.8 \times 10^{-5} \mathrm{mSv}\right)$. This contribution was mostly from Area 12 tritium releases. Because these are normal operations for the NTS, the calculated dose was included in the site's routine dose estimates.

Rockwell International's Santa Susana Field Laboratory (RI) has been undergoing decommissioning and decontamination activities for the last five years. Small amounts of residual contamination remain on the site. A total of $1.1 \times 10^{-5} \mathrm{Ci}\left(4.1 \times 10^{5} \mathrm{~Bq}\right)$ of mixed fission products were assessed as the area source term from resuspension calculations based on soil concentrations. The dose from area (non-point) sources to an offsite individual was $3.4 \mathrm{X}$ $10^{-5} \mathrm{mrem} / \mathrm{yr}\left(3.4 \times 10^{-7} \mathrm{msv} / \mathrm{yr}\right)$. While the dose from non-point sources was greater than the point source dose reported for the facility, the sum of the two was still much lower than the Subpart $\mathrm{H}$ requirement.

The West Valley Demonstration Project (WVDP) has identified two potential non-point sources. These are the low-level waste treatment lagoons and the contaminated soil containment area. Source term calculations used evaporation rates based on local meteorological data, radionuclide concentrations in each lagoon and radionuclide partitioning factors. Source term estimates for the soil bins was obtained by assuming that one percent of the bin contents may be subject to atmospheric dispersion. The activity released was estimated using the maximum allowable radionuclide concentration in soil, the bin volume, an assumed soil density and an emission factor of 0.001 for particulate solids. The total EDE from non-point sources at WVDP was 0.1 $\mathrm{mrem} / \mathrm{yr}\left(1 \mathrm{x} 10^{-3} \mathrm{msv} / \mathrm{yr}\right)$ and is based on conservative assumptions. The dose is primarily due to the release of $1.1 \mathrm{x}$ 
$10^{-3} \mathrm{Ci}\left(4.1 \times 10^{7} \mathrm{~Bq}\right)$ of ${ }^{129} \mathrm{I}$. The concentration of iodine in air is only $4 \%$ of regulatory standards (see 40 CFR Part 61, Appendix E, Table 2), and the total dose is about $1 \%$ of the Subpart $\mathrm{H}$ standard.

In 1993, all emissions originated from diffuse sources at the Pantex Plant. A total of $0.31 \mathrm{Ci}(0.011 \mathrm{TBq})$ of tritium was released from equipment calibrations, a past accident site, D\&D activities at a reservoir, and the Burning Ground. Single release points were assumed for each location in calculating the dose to the nearest offsite individual for each location. The total dose from tritium was $5.7 \times 10^{-5} \mathrm{mrem} / \mathrm{yr}\left(5.7 \times 10^{-7}\right.$ $\mathrm{mSv} / \mathrm{yr}$ ) and was well below the dose standard.

The Grand Junction Projects office has a remedial action project which was the only source of diffuse emissions reported for 1993 by the site. Remediation of tailings from uranium mining resulted in the emissions of $2.6 \times 10^{-6} \mathrm{Ci}\left(9.6 \times 10^{4} \mathrm{~Bq}\right)$ from the ${ }^{238} \mathrm{U}$ decay chain. Individual nuclide emissions were calculated based on activity-per-unit mass for each radionuclide. The resulting dose that was assessed for these emissions was $0.0021 \mathrm{mrem} / \mathrm{yr}\left(2.1 \times 10^{-5} \mathrm{mSv} / \mathrm{yr}\right)$.

Fernald Environmental Management Project (FEMP) reports a dose to the MEI offsite of $6.6 \times 10^{-3} \mathrm{mrem} / \mathrm{yr}\left(6.6 \times 10^{-5} \mathrm{mSv} / \mathrm{yr}\right)$. Engineering calculations were performed to estimate diffuse and point radionuclide sources. Past source sampling activities at the FEMP were used to produce the radionuclide specific activity to mass conversion factors ( $\mathrm{Ci} / \mathrm{kg} \mathrm{U}$ ) that were used in the calculations. The total releases from the FEMP were $2.8 \times 10^{-4}$ $\mathrm{Ci}\left(1.0 \times 10^{7} \mathrm{~Bq}\right)$ uranium and decay products. Diffuse source emissions accounted for the majority of the dose to the MEI offsite. The total dose was estimated to be $0.016 \mathrm{mrem} / \mathrm{yr}(1.6 \mathrm{X}$ $10^{-4} \mathrm{mSv} / \mathrm{yr}$ ). 
The soil surrounding the Rocky flats Plant (RFP) is the primary source of diffuse emissions at that site. Since normal operations ceased in 1989, the resuspension of contaminated soil is the primary source of radionuclide emissions. Non-point sources are composed of $4.1 \times 10^{-5} \mathrm{Ci}\left(1.5 \times 10^{6} \mathrm{~Bq}\right) \mathrm{mixed}$ uranium and transuranics. CAP88-PC used in conjunction with the soil sampling isopleth concentrations calculated a dose offsite of $1.6 \times 10^{-3} \mathrm{mrem} / \mathrm{yr}\left(1.6 \times 10^{-5} \mathrm{msv} / \mathrm{yr}\right)$ in 1993 .

Eight DOE-owned or -leased remedial action sites are operated under the Formerly Utilized Sites Remedial Action Program (FUSRAP) and the Surplus Facilities Management Program (SFMP). These programs assess diffuse source emissions as the primary contributor to the offsite dose to the public. FUSRAP/SFMP sites reduce offsite migration of radioactive materials by utilizing vegetation and impermeable covers over contaminated soil areas. With the exception of Weldon Springs site (WSSRAP), which uses environmental monitoring data to demonstrate compliance with the subpart $H$ standard, these temporary storage and disposal sites use computer environmental models to determine the release and the dose to the public. Methodology given in the U.S. Environmental Protection Agency's "Rapid Assessment of Exposure to Particulate Emissions from Surface Contamination Sites (EPA/600/8-85.002)" was used to model the resuspended soil release, and the CAP-88 computer model was used to model atmospheric dispersion and the dose to the MEI offsite. Table 4 provides estimates for the total activity of uranium and decay products released from each of these storage and disposal facilities. Estimates of EDE resulting from the evaluations were less than $1.0 \mathrm{mrem} / \mathrm{yr}(0.01 \mathrm{mSv} / \mathrm{Yr})$, which is one tenth of the subpart $H$ standard (Table 6 ). 


\subsection{Unplanned Releases to the Atmosphere}

Nine Department of Energy Facilities reported unplanned releases during 1993. The releases are summarized in Table 4. The total unplanned release from DOE consisted of $100 \mathrm{Ci}(3.7 \mathrm{TBq})$ of tritium, $9 \mathrm{Ci}(0.33 \mathrm{TBq})$ of noble gases, $2 \times 10^{-4} \mathrm{Ci}\left(7.4 \times 10^{6}\right.$ $\mathrm{Bq})$ of transuranics, and approximately $8 \mathrm{Ci}(0.3 \mathrm{TBq})$ of all other radionuclides. The exposure from any one unplanned release to an offsite receptor was at a dose level of less than 0.08 mrem ( $8 \times 10^{-4} \mathrm{mSv}$ ) and was well below the $10 \mathrm{mrem} / \mathrm{yr}$ dose standard specified in 40 CFR Part 61, Subpart $H$. Individual unplanned releases are summarized below. Additional details can be found in the Annual Site Environmental Reports (ASER's) for each site of interest.

Two unplanned releases of radionuclides occurred in 1993 at LANL. One involved the release of $7 \mu \mathrm{g}$ of depleted uranium and the other $35.5 \mathrm{Ci}(1.3 \mathrm{TBq})$ of tritium. The depleted uranium was inadvertently released on June 23 during an open burn. The dose to the MEI was estimated to be $4 \times 10^{-11}$ mrem $\left(4 \times 10^{-13} \mathrm{mSv}\right.$ ). The unplanned tritium release occurred over several days, beginning August 30 and ending september 3. The estimated dose to LANL's MEI was 1 mrem ( $1 \times 10^{-2} \mathrm{mSv}$ ).

The Pinellas Plant had an unplanned release of Krypton-85 (noble gas) on April 20 which resulted from an equipment malfunction. This $9.3 \mathrm{Ci}(0.34 \mathrm{TBq})$ release was well-below the 24-hour reportable quantity release threshold established by the EPA regulation implfementing the Comprehensive Environmental Response, Compensation, and Liability Act (CERCLA) for Krypton85. Dose calculations estimated that the exposure to the nearest resident was approximately $6 \times 10^{-5} \mathrm{mrem}\left(6 \times 10^{-7} \mathrm{mSv}\right)$.

The Princeton Plasma Physics Laboratory had an unplanned release of $11.3 \mathrm{Ci}(0.42 \mathrm{TBq})$ of tritium gas and $0.013 \mathrm{Ci}\left(4.8 \times 10^{8} \mathrm{~Bq}\right)$ 
of tritium oxide on July 19. The release was caused by a "maintenance evolution". The estimated dose to the nearest receptor was $2 \times 10^{-5}$ mrem $\left(2 \times 10^{-7} \mathrm{mSv}\right)$.

The Oak Ridge Reservation had unplanned releases at two of its facilities. A routine filter analysis at the $\mathrm{Y}-12$ plant revealed elevated emissions of enriched uranium. The release was estimated to be less than the DOE reporting limit of $10 \mathrm{~g}$. The release from the $\mathrm{K}-25$ Site on May 5 occurred as a result of a power failure. The total release amounted to approximately 10 seconds of feed material. The estimated dose to the nearest offsite individual was $3 \times 10^{-5} \operatorname{mrem}\left(3 \times 10^{-7} \mathrm{mSv}\right)$.

An unplanned release of approximately $0.5 \mathrm{lb}(0.2 \mathrm{~kg})$ of $\mathrm{UF}_{6}$ at the Paducah Gaseous Diffusion Plant Vaporizer UF 6 Feed Facility occurred over a one hour period on september 7 . The emission originated from a 0.5 -inch $(1.3 \mathrm{~cm})$ crack in a 2 -inch $(5 \mathrm{~cm})$ diameter, 60-foot $(17 \mathrm{~m})$ long pipe header, which was not in use at the time. The resulting offsite dose was approximately $5 \mathrm{x}$ $10^{-4}$ mrem ( $5 \times 10^{-6} \mathrm{mSv}$ ) to the MEI. Later in the year, $\mathrm{UF}_{6}$ was released in Building $\mathrm{C}-337$. A UF ${ }_{6}$ compressor and its associated motor and piping were extensively damaged. Several workers were found to have elevated uranium exposure, but no offsite release was reported. In the past, "whiffs and puffs" of UF 6 were released from the Plant as a result of certain maintenance operations. There were none reported for 1993.

Technetium-99 emissions from the Portsmouth Gaseous Diffusion Plant were above normal from January through September. The largest releases occurred in March, April, and June. Total technetium releases are estimated to be $7.8 \mathrm{Ci}(0.29 \mathrm{TBq})$ for the year. Clean-up operations for shutdown of the diffusion cascade resulted in the emission of the technetium at higher levels than had occurred during normal production operations. Later in the 
year, magnesium fluoride traps were discovered to effectively trap the technetium.

One unplanned tritium release occurred at Lawrence Berkeley Laboratory in 1993. The release resulted from a failure to replace a silica gel bed in Building 75. It is believed that HTO trapped on the silica gel slowly migrated through the bed until it began to be released to the Building 75 stack on August 15 . Approximately $44 \mathrm{Ci}$ (1.6 TBq) of HTO was released to the environment during that week. The dose to the MEI was estimated to be $0.8 \mathrm{mrem}\left(8 \times 10^{-4} \mathrm{mSv}\right)$.

A single unplanned release occurred at the LLNL Site. The release was discovered in september, but is believed to have begun in early June. The source of the release was a thorium-228 experiment being conducted in a HEPA-filtered glove box. The release resulted from the build-up of radon-220 decay products which reached the trigger level in September. Approximately 16 $\mathrm{Ci}(0.59 \mathrm{TBq})$ of radon-220 was released over the entire period and resulted in a dose of approximately $3 \times 10^{-4}$ mrem $\left(3 \times 10^{-6}\right.$ $\mathrm{mSv}$ ) to the MEI.

Three unplanned releases occurred at the Savannah River Site in 1993. Two were tritium releases and the third was a plutonium release. On March 9, less than $1.7 \mathrm{Ci}(0.063 \mathrm{TBq})$ of tritium was released during compaction of low-level radioactive waste. On December 9, approximately $8 \mathrm{Ci}(0.3 \mathrm{TBq})$ of tritium was released to the atmosphere during a routine loading operation in the Tritium Facilities. The plutonium release, which occurred between December 27 and 28, resulted during a routine transfer between the F-Area underground tanks. Approximately $1.9 \times 10^{-4}$ $\mathrm{Ci}\left(7.0 \times 10^{6} \mathrm{~Bq}\right)$ of plutonium-238 and $2.4 \times 10^{-5} \mathrm{Ci}\left(8.9 \times 10^{5}\right.$ $\mathrm{Bq})$ of plutonium-239 were released to the air. The dose to the MEI from these releases was approximately 0.02 mrem $\left(2 \times 10^{-4}\right.$ $\mathrm{mSv}$ ) . 


\section{SECTION 2. SUPPLEMENTAL INFORMATION}

DOE radionuclide emissions to the atmosphere that are subject to Subpart $H$ of 40 CFR Part 61 include point source or stack emissions from routine operations and non-point source or diffuse emissions such as resuspended material from contaminated soil areas. Most point source emissions are routinely monitored while many of the diffuse sources and potentially low-emission point sources are unmonitored. The emissions from these non-point sources are either calculated using computer modeling or derived using area air sampling. There are other sources of radionuclide emissions reported under subpart $H$ that are unplanned but are assessed and included as part of the overall site emissions. Additionally, some DOE sites have radionuclide releases to the atmosphere that are not covered under subpart $H$. These sources involve radon emissions which are covered by other sections of the NESHAPs and subject to environmental protection limits other than the $10 \mathrm{mrem} / \mathrm{yr}(0.1 \mathrm{mSv} / \mathrm{yr})$ standard of Subpart $\mathrm{H}$. The radon emissions from DOE sites are discussed in subsection 2.1 and summarized in Tables 5 and 6 .

Other supplemental information provided in this section includes the reported collective doses for each DOE site. The collective dose is the sum of the per capita dose over the number of individuals exposed within 50 miles $(80 \mathrm{~km})$ of the DOE site boundary and is reported in person-rem. The collective doses for DOE sites are discussed in subsection 2.2 .

Subsection 2.3 presents a summary of the supplemental information provided by DOE sites on their compliance activities and the status of compliance with 40 CFR Part 61, Subpart H. Information is presented on DOE efforts to comply with the emission monitoring requirements. 


\subsection{Radon Emissions}

Radon-222 (the decay product of radium-226 and uranium-238) emissions from DOE storage and disposal sites are regulated under Subpart $Q$ of 40 CFR Part 61. Sites containing uranium mill tailings are regulated under subpart $T$ of $40 \mathrm{CFR}$ Part 61 . The standards for radon emissions under subparts $Q$ and $T$ are expressed in terms of radon flux and are averaged over the radon source. The radon source is considered to be an isolated pile, impoundment or structure containing radium. Unlike Subpart $H$, Subpart $Q$ of 40 CFR Part 61 contains no reporting requirements but identifies the Federal Facilities Agreement under the Comprehensive Environmental Response Compensation and Liability Act (CERCLA) as a means of demonstrating compliance with its requirements. Subpart $T$ of 40 CFR Part 61 requires pre-closure radon flux measurements at uranium mill tailings disposal sites, which must be reported to EPA during various stages of the final disposal process. DOE sites subject to 40 CFR Part 61 , subpart $T$ are exempt from Subpart $H$ for radionuclide particulate emissions, which is not the case for sites subject to $40 \mathrm{CFR}$ Part 61 , Subpart Q.

The regulations under NESHAPs do not address sources of radon-220 (the decay product of radium-224, thorium-232 and uranium-232). Because of its short (55 sec) half-life, it is generally assumed that radon-220 is of less concern to the public dose than is radon-222 which has a 3.8 day half-life. Nevertheless, DOE has collected from its sites radon-220 emission data and modeled doses. This effort included flux measurements at storage or disposal facilities that handle wastes containing significant concentrations of thorium-232 and uranium-232. In addition to waste management operations, DOE has also investigated the contribution of radon-220 to doses associated with its normal operations. The doses from radon-220 emissions result primarily from exposure to its progeny (polonium-216, lead-212, bismuth- 
212, thallium-208, and polonium-212). CAP88 models the dose from radon-220 emissions, however the doses are generally negligible because of its short half-life (55 sec), and the code does not include the dose from long-lived progeny. The approach generally involves the assumption that all radon-220 has decayed to its first long-lived daughter (lead-212) prior to transport beyond the site boundary. This assumption may provide a conservative estimate of the radon-220 dose depending on the location of the receptor. However, methods and assumptions used are not specified in all site reports containing radon-220 dose estimates. A discussion of radon sources at specific DOE sites follows.

The Mound Plant has one source of radon-222 in addition to natural emissions from soil and building material. This source results from residual radium-226 associated with an operation that was terminated in the early 1950s. The radon-222 emission rate from this and the natural sources is estimated to be $1.1 \mathrm{Ci}$ (0.04 TBq) for 1993. The dose to the public calculated for 1993 is approximately $2 \times 10^{-3} \operatorname{mrem}\left(2 \times 10^{-5} \mathrm{mSv}\right)$.

The majority of all radon-220 emitted from DOE sites during 1993 was released from Argonne National Laboratory. A total of $2.0 \mathrm{X}$ $10^{3} \mathrm{Ci}$ ( $74 \mathrm{TBq}$ ) were released from M-Wing of Building 200, which is a $30 \%$ reduction over the 1992 release levels. This source contributed a dose of $0.24 \mathrm{mrem}\left(2.4 \times 10^{-3} \mathrm{mSv}\right)$ to the ANL MEI for 1993 .

The Inhalation Toxicology Research Institute released $0.088 \mathrm{Ci}$ $\left(3.2 \times 10^{9} \mathrm{~Bq}\right)$ of radon-220 and $3 \times 10^{-3} \mathrm{Ci}\left(1.1 \times 10^{8} \mathrm{~Bq}\right)$ of radon-222 from stack PE007. The dose to the MEI offsite from both the radon-220 and radon-222 emissions was estimated to be $2.2 \times 10^{-7} \operatorname{mrem}\left(2.2 \times 10^{-9} \mathrm{mSv}\right)$. 
The Bettis Laboratory released $650 \mathrm{Ci}$ (24 TBq) of radon-220. The estimated dose to the MEI from this release was 0.27 mrem $\left(2.7 \times 10^{-3} \mathrm{mSv}\right)$. Bettis also released $0.98 \mathrm{Ci}(0.036 \mathrm{TBq})$ of radon-222. The estimated dose to the MEI was $4.5 \times 10^{-3}$ mrem ( $\left.4.5 \times 10^{-5} \mathrm{mSv}\right)$, which is over three times the non-radon dose from routine site releases.

A new project at the Hanford Site resulted in additional emissions of radon-220 and radon-222 during 1993. This new source at the Building 327 accounted for the majority of the radon-220 emissions at the Hanford site. The historic radon-220 source at Hanford was from residual radioactive materials in the PUREX facility. These radon-220 emissions have declined steadily since the facility was shut down. Total radon-220 emissions were $12 \mathrm{Ci}(0.44 \mathrm{TBq})$ from PUREX and $85 \mathrm{Ci}(3.1 \mathrm{TBq})$ from Building 327. The estimated dose to the MEI from all Hanford radon-220 emissions for 1993 was $0.008 \mathrm{mrem}\left(8 \times 10^{-5} \mathrm{mSv}\right)$. The radon-222 emissions from Building 327 was $1.5 \mathrm{Ci}(0.056 \mathrm{TBq})$. The dose to the MEI from radon-222 was estimated to be 0.002 mrem $\left(2 \times 10^{-5} \mathrm{mSv}\right)$. The dose from radon emissions at Hanford is at about the same level as the dose from all other radionuclide emissions at the site.

The Lawrence Livermore National Laboratory had a $16 \mathrm{Ci}$ ( $0.59 \mathrm{TBq})$ unplanned release of radon-220 (see section 1.6) which resulted from the decay of thorium-228 used in an experiment. The dose to the MEI offsite from this release was approximately $3 \times 10^{-4}$ mrem ( $3 \times 10^{-6} \mathrm{mSv}$ ) . Radon-222 emissions from routine experiments were estimated to be $6 \times 10^{-5} \mathrm{Ci}\left(2.2 \times 10^{6} \mathrm{~Bq}\right)$ with a corresponding dose to the MEI of $2 \times 10^{-7}$ mrem (2 $\times 10^{-9} \mathrm{mSv}$ ). 


\subsection{Collective Dose Estimates}

In addition to the dose to the MEI for each DOE site, DOE requires, through order DOE 5400.5, that the collective dose to populations within 50 miles $(80 \mathrm{~km})$ of the sites to be evaluated and reported annually. Although this information is not required in the radionuclide air emissions reports that are submitted to EPA under the NESHAPs, all facilities were requested by DOE headquarters to provide collective dose data as available for inclusion in this summary report.

The collective dose for radionuclide air emissions is provided in the output of the EPA-approved modeling computer codes such as CAP88-PC. The collective population dose is obtained by computing the average dose for a given geographical sector and multiplying that dose by the number of persons residing in that sector, and then summing over all sectors. The collective dose is expressed in person-rem and is a quantity that may be used as basis for assessing collective risk. The results given in Table 7 report that the collective dose from all DOE operations during 1993 was about 95 person-rem ( 0.95 person-Sv). Of this total, $90 \%$ resulted from operations at eight sites (ANL, BET, BNL, LANL, LLNL-300, ORR, PORT, and SRS).

Many of the collective doses reported in the table include both normal operating releases and all other sources of airborne radionuclide emissions. Several DOE sites are located in close proximity to each other, near major urban areas, therefore some individuals within these areas may be exposed to emissions from more than one DOE site. According to risk estimates currently in use by EPA (1989a), the collective dose from DOE facilities is much lower than that which would be expected to produce a single cancer death during the lifetimes of the exposed populations. It is also many orders of magnitude lower than the dose received by these populations from natural background radiation. 


\subsection{Status of Compliance with Emission Monitoring Requirements in 40 CFR Part 61 , subpart $H$}

Continuous monitoring of radioactive effluent is required at all emission points that could potentially result in an offsite dose exceeding $1 \%$ of the $10 \mathrm{mrem} / \mathrm{yr}(0.1 \mathrm{mSv} / \mathrm{yr})$ EDE standard. In determining whether the continuous monitoring requirements apply, the potential releases from each emission point (stack or vent) must be evaluated in the absence of any emission control devices, but assuming that facility operations are otherwise normal. 40 CFR Part 61, Subpart $H$ specifies that EPA and American National Standards Institute (ANSI) procedures for the measurement of effluent flow rates and for radionuclide sampling be utilized at these stacks. Alternate procedures for emission monitoring may be used with prior approval from EPA. Quality Assurance (QA) requirements that employ specific EPA methods also must be met where continuous monitoring is being implemented. Periodic confirmatory measurements are required at all emission points that do not require continuous monitoring.

Current monitoring programs at DOE sites are sufficient to demonstrate that the protective requirements of the rule are being met. DOE continues its efforts at a number of sites to conduct the necessary upgrades to emission monitoring programs that will allow DOE to demonstrate compliance with all procedural provisions of the subpart $H$ in the near future. DOE has twelve sites that are considered major sources of radionuclide emissions subject to the continuous monitoring requirements of Subpart $H$. of these twelve DOE sites, six (INEL, LLNL, ORR, PAD, PORT, \& SRS) are in full compliance with the EPA continuous monitoring requirements. Two DOE sites (HANF \& LBL) have signed individual Federal Facilities Compliance Agreements (FFCA) with their EPA regional office and are in the process of completing upgrades. Two sites (LANL \& MLM) are actively negotiating separate FFCA's 
with their EPA regional offices. One site (BNL) is completing upgrades under an informal agreement with its EPA regional office and another site (RFP) was under a compliance order issued by its EPA regional office. Although the compliance order has expired, RFP and EPA have agreed that the alternate sampling methodology (single-point sampling with the shrouded probe) approved by EPA will be used at RFP to meet the continuous monitoring requirements and satisfy the EPA concerns addressed by the compliance order.

All other DOE sites are considered minor sources and either have completed or are at various stages of completing the protocol for periodic confirmatory measurements at their sites. These measurement protocols are being developed in coordination with their EPA regional offices and are being submitted to the EPA regional offices as a means of demonstrating compliance with the these requirements.

\section{SECTION 3. SUMMARY OF DOE/EPA ACTIVITIES AND INITIATIVES}

DOE headquarters continues to interact closely with EPA headquarters in a number of areas that aid in promoting consistent and uniform implementation of the radionuclide NESHAPs across DOE operations offices and EPA regional offices. The following is a summary of the most important initiatives.

\subsection{EPA/DOE Memorandum of Understanding}

A Memorandum of Understanding (MOU) between EPA and DOE has been developed. This mutual effort between agencies is intended to clarify provisions of 40 CFR Part 61, subpart $H, I, Q$, and $T$ of the radionuclide NESHAPs. The MOU will act as guidance to DOE operations offices and EPA regional offices on how to interpret 
certain provisions of the rule that are silent to specific technical details needed to clarify the implementation process at DOE sites. The MOU is intended to provide a platform for which site-specific negotiations can begin between DOE operations offices and EPA regional offices. The MOU is not intended to supersede or replace applicable statutes, regulations or compliance agreements nor is it intended to specify any preferred enforcement approach or address any site-specific issues.

The MOU was reviewed by EPA headquarters and regional offices and subsequently by DOE program and field offices. It was signed by the EPA Assistant Administrator for Air and Radiation, Mary D. Nichols, on September 29, 1994, and by DOE Assistant Secretary for Environment, Safety, and Health, Tara o'Toole, and became effective April 5, 1995.

\subsection{EPA Approval of Alternate Reference Method}

DOE headquarters requested EPA headquarters to approve the use of an alternative effluent monitoring approach that could be implemented DOE-wide. The alternate reference method (ARM) is based on single-point sampling and permits the use of a "shrouded probe". The ARM was approved by the EPA Assistant Administrator for Air and Radiation, Mary D. Nichols, and documented in a transmittal to Ray Pelletier, DOE, Office of Environmental Guidance, on November 21, 1994. In the letter, EPA specified conditions that will be met at each DOE stack for which the alternate approach is to be applied. In instances where the use of the alternate approach is intended but all specified conditions are not met, DOE should submit a request to the appropriate EPA regional office for a stack-specific evaluation and approval. That type of request will be evaluated by EPA on a case-by-case basis and will require DOE to submit to EPA additional information. The alternate approach involving the use 
of single point sampling with a shrouded probe represents a newer effluent monitoring technology that will improve data quality by reducing sample line loss. The alternate approach will be adopted by the ANSI committee responsible for revising the standard ANSI N 13.1 .

\subsection{EPA report on Diffuse Source Estimation}

EPA headquarters developed a draft report entitled "Methods for Estimating Diffuse and Fugitive Air Emissions of Radionuclides at DOE Facilities". The EPA report was developed to address the need for uniform guidance on appropriate methodologies to be used for assessing the radionuclide emissions into the atmosphere from diffuse sources at DOE sites. DOE provided extensive comments on the report. EPA strengthened the section on the use environmental measurements to assess diffuse source emissions. The revised report, now entitled: "Considerations in Developing and Using Methods for Diffuse and Fugitive Air Emissions of Radionuclides at DOE Facilities", has been issued to DOE Operations offices to use in the selection and development of methods for assessing emissions from diffuse (non-point) sources. EPA will use the methods and approaches established in the report as the basis for guidance to EPA regional offices. This guidance should aid the regions in assessing the methods used at DOE sites for evaluating their diffuse source emissions. 


\section{REFERENCES}

Beres, D. A. 1990. The Clean Air Act Assessment Package-1988 (CAP-88). A Dose and Risk Assessment Methodology for Radionuclide Emissions to Air. Vol. 1, User's Manual. U.S. Environmental Protection Agency, Office of Radiation Programs, Washington, D.C.

International Commission on Radiological Protection (ICRP). 1977. Recommendations of the International Commission on Radiological Protection. ICRP Publication 26, Pergamon Press, Oxford.

International Commission on Radiological Protection (ICRP). 1979-1982. Limits for Intakes of Radionuclides by Workers. ICRP Publication 30, Annals of the ICRP, Vol. 2, No. 3/4, through Vol. 8, No. 4, Pergamon Press, New York.

Parks, B. S. 1992. User's Guide for CAP88-PC. Version 1.0. 402-B-92-001. Office of Radiation Programs, U. S. Environmental Protection Agency, Las Vegas, Nevada.

U. S. Environmental Protection Agency (EPA). 1989a. Risk Assessment Methodology. Draft Environmental Impact statement for Proposed NESHAPS for Radionuclides. Background Information Document. Vol. 1, EPA 520/1-89-005, EPA Office of Radiation Programs, Washington D. C.

U.S. Environmental Protection Agency (EPA). 1989b. User's Guide for AIRDOS-PC. Version 3.0. EPA/520/6-89-035, EPA Office of Radiation Programs, Las Vegas, NV.

U.S. Environmental Protection Agency (EPA). 1989c. User's Guide for the COMPLY Code. Rev. 1, EPA/520/1-89-003, EPA office of Radiation Programs, Washington, D.C. 
U. S. Nuclear Regulatory Commission (NRC). 1991. Air Sampling in the Workplace. NUREG-1400 (Draft), NRC, Washington, D. C. 


\section{FIGURES}

Figure 1. U. S. Department of Energy Site Locations and U.S. Environmental Protection Agency Regions

Figure 2. 1993 Annual Maximum Individual Dose Reported for each U. S. Department of Energy Facility 


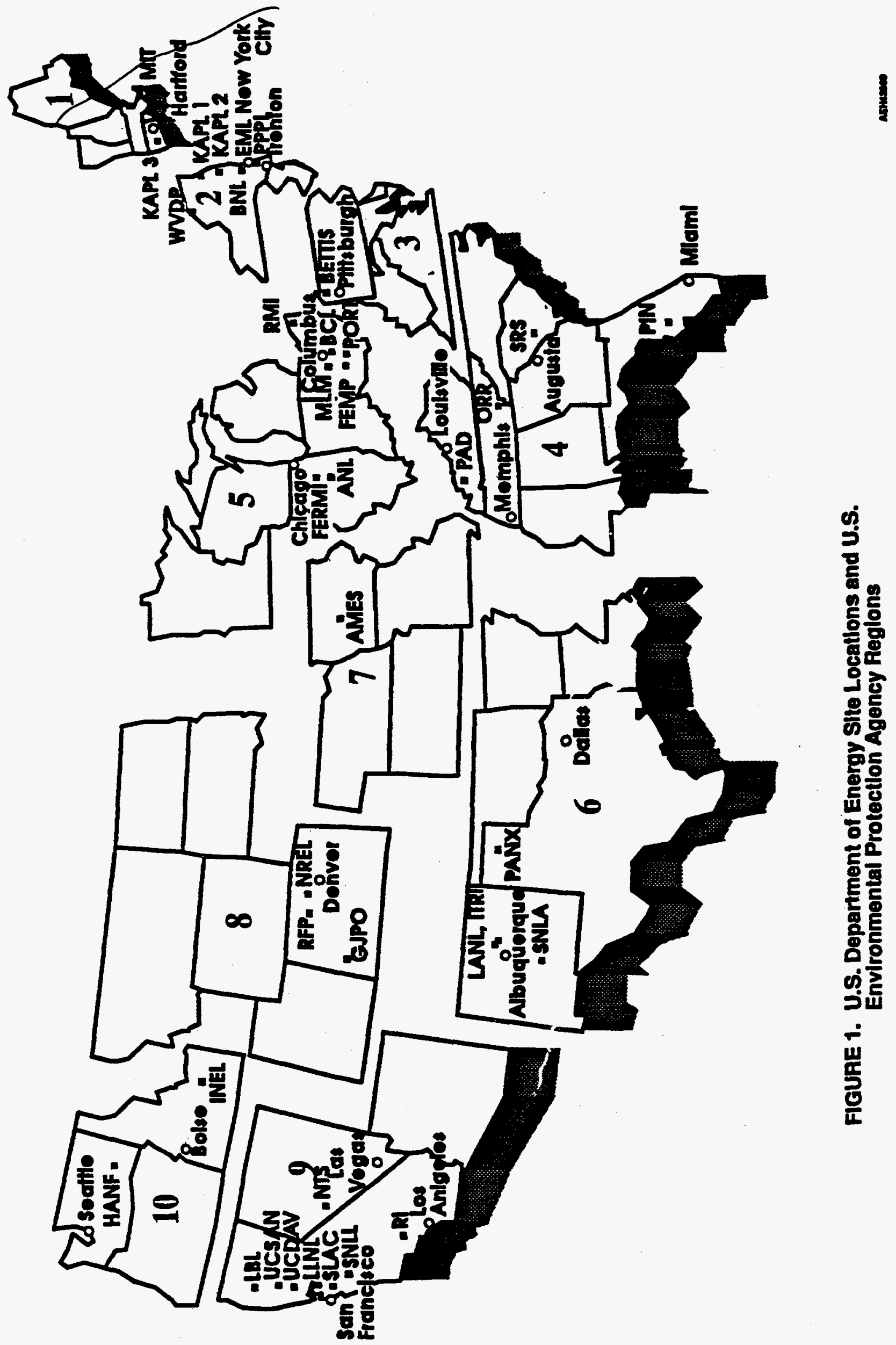




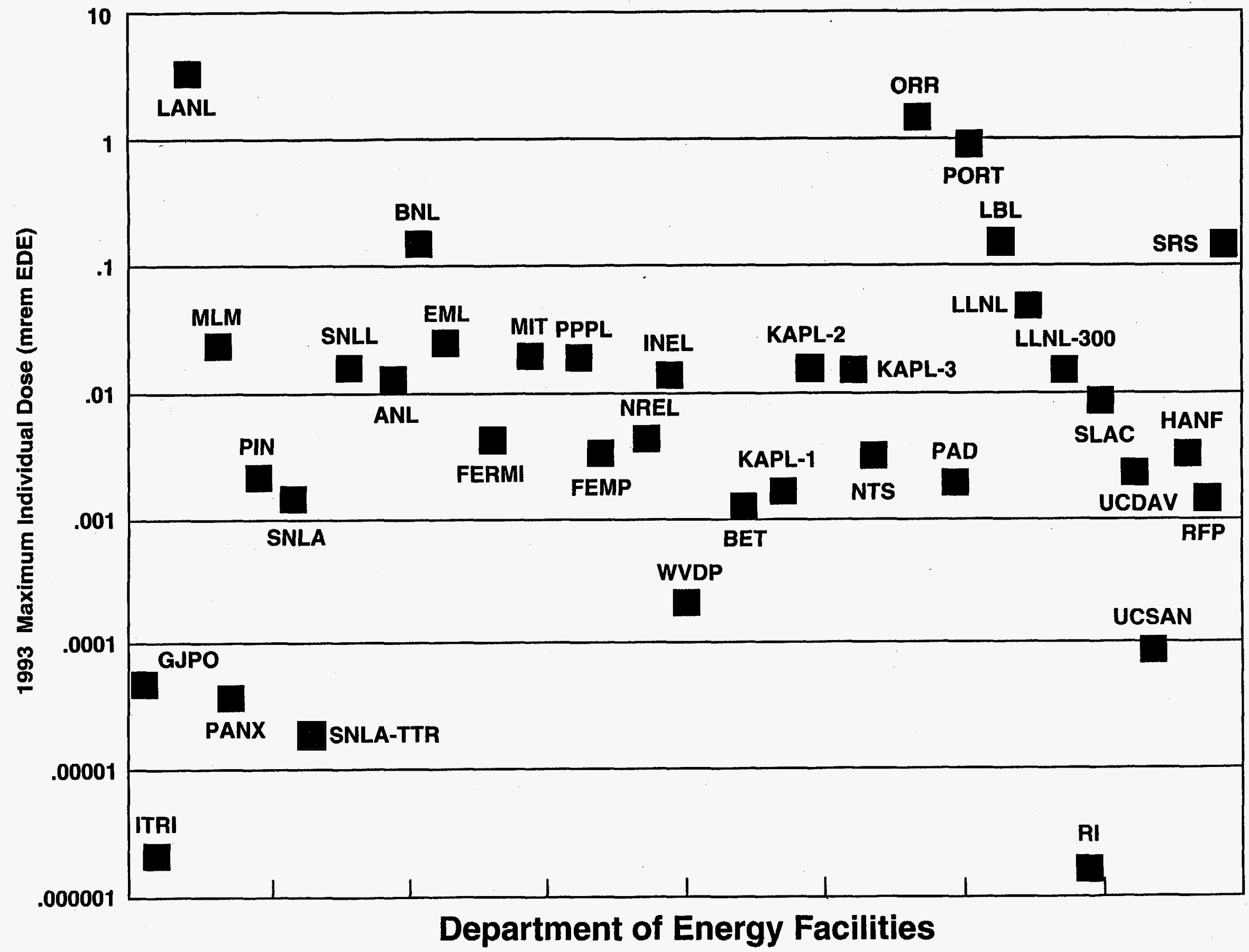




\section{TABLES}

Table 1. U. S. Department of Energy Sites by Operations Öfice and Location

Table 2. Summary of Airborne Radionuclide Releases from Normal Operations at Department of Energy Facilities During Calendar Year 1993

Table 3. Dose to the Maximally Exposed offsite Individual from Radionuclide Emissions to Air at Department of Energy Facilities During Calendar Year 1993 - Normal Operations

Table 4. Summary of Airborne Radionuclide Emissions from Department of Energy Facilities for Calendar Year 1993 - Sources Other than Normal Operations

Table 5. Summary of Airborne Radon Releases from Department of Energy Facilities During Calendar Year 1993.

Table 6. Dose to the Maximally Exposed offsite Individual From Airborne Radionuclide Emissions from Department of 
Energy Facilities During Calendar Year 1993 - Sources other than Normal operations

Table 7. Collective (population) Dose to the 80-km Population for Airborne Radionuclide Emissions from Department of Energy Facilities During Calendar Year 1993 
DOE

Operations

Site

office

Abbreviation

Site Name

Site Location

\section{U.S. DOE Production Sites and Research Facilities}

\begin{tabular}{|c|c|c|c|}
\hline $\begin{array}{l}\text { Al buquerque } \\
(A L)\end{array}$ & $\begin{array}{l}\text { GJPO } \\
\text { ITRI } \\
\text { KCP } \\
\text { LANL } \\
\text { MLM } \\
\text { PANX } \\
\text { PIN } \\
\text { SNLA } \\
\text { SNLA-TTR } \\
\text { SNLL }\end{array}$ & $\begin{array}{l}\text { Grand Junction Project Office } \\
\text { Inhalation Toxicology Research Institute } \\
\text { Kansas City Plant, Allied-Signal Aerospace Co. } \\
\text { Los Alamos National Laboratory } \\
\text { Mound Plant } \\
\text { Pantex Plant } \\
\text { Pinellas Plant } \\
\text { Sandia National Laboratories, } \\
\text { (Albuquerque) New Mexico } \\
\text { Sandia National Laboratories, (Albuquerque) } \\
\text { New Mexico - Tonopah Test Range } \\
\text { Sandia National Laboratories, } \\
\text { (Livermore) California }\end{array}$ & $\begin{array}{l}\text { Grand Junction, CO } \\
\text { Albuquerque, NM } \\
\text { Kansas City, MO (1) } \\
\text { Los Alamos, NM } \\
\text { Miamisburg, OH } \\
\text { Amarillo, TX } \\
\text { Largo, FL } \\
\text { Albuquerque, NM } \\
\text { Tonopah, NV } \\
\text { Livermore, CA }\end{array}$ \\
\hline Chicago (CH) & $\begin{array}{l}\text { AMES } \\
\text { ANL } \\
\text { BCL } \\
\text { BNL } \\
\text { EML } \\
\text { FERMI } \\
\text { MIT } \\
\text { PPPL }\end{array}$ & $\begin{array}{l}\text { Ames Laboratory } \\
\text { Argonne National Laboratory } \\
\text { Battelle Columbus Laboratory. West Jefferson Site } \\
\text { Brookhaven National Laboratory } \\
\text { Environmental Measurements Laboratory } \\
\text { Fermi National Accelerator Laboratory } \\
\text { Massachusetts Institute of Technology } \\
\text { Bates Linear Accelerator Center } \\
\text { Princeton Plasma Physics Laboratory }\end{array}$ & $\begin{array}{l}\text { Ames, IA (1) } \\
\text { Argonne, IL } \\
\text { Columbus, OH (2) } \\
\text { Upton, NY } \\
\text { New York, NY } \\
\text { Batavia, IL } \\
\text { Middleton, MA } \\
\text { Princeton, NJ }\end{array}$ \\
\hline Fernald (FN) & FEMP & Fernald Environmental Management Project & Fernald, $\mathrm{OH}(3)$ \\
\hline Golden (GOL) & NREL & National Renewable Energy Laboratory & Golden, $\operatorname{Co}(4)$ \\
\hline Idaho (ID) & $\begin{array}{l}\text { INEL } \\
\text { WVDP }\end{array}$ & $\begin{array}{l}\text { Idaho National Engineering Laboratory } \\
\text { West Valley Demonstration Project }\end{array}$ & $\begin{array}{l}\text { Idaho Falls, } 10 \\
\text { West Valley, NY }\end{array}$ \\
\hline $\begin{array}{l}\text { Naval Reactors } \\
\text { (NR) (5) }\end{array}$ & $\begin{array}{l}\text { 8ET } \\
\text { KAPL-1 } \\
\text { KAPL-2 } \\
\text { KAPL-3 }\end{array}$ & $\begin{array}{l}\text { Bettis Atomic Power Laboratory. Bettis Site } \\
\text { Knolls Atomic Power Laboratory, Knolls Site } \\
\text { Knolls Atomic Power Laboratory, Kesselring Site } \\
\text { Knolls Atomic Power Laboratory. Windsor Site }\end{array}$ & $\begin{array}{l}\text { West Mifflin, PA } \\
\text { Schenectady, NY } \\
\text { West Milton, NY } \\
\text { Windsor, CT }\end{array}$ \\
\hline Nevada (NV) & NTS & Nevada Test Site & Mercury, NV \\
\hline Oak Ridge (OR) & $\begin{array}{l}\text { ORR } \\
\text { PAD } \\
\text { PORT } \\
\text { RMI }\end{array}$ & $\begin{array}{l}\text { Oak Ridge Reservation } \\
\text { Paducah Gaseous Diffusion Plant } \\
\text { Portsmouth Gaseous Diffusion Plant } \\
\text { RMI Titanium Company Extrusion Plant }\end{array}$ & $\begin{array}{l}\text { Oak Ridge, TN } \\
\text { Paducah, } \mathrm{KY} \\
\text { Piketon, } \mathrm{OH} \\
\text { Ashtabula, } \mathrm{OH}(1,6)\end{array}$ \\
\hline $\begin{array}{l}\text { Oakl and (OAK) } \\
\text { (7) }\end{array}$ & $\begin{array}{l}\text { LBL } \\
\text { LEHR } \\
\text { LLNL } \\
\text { LLNL Site } 300 \\
\text { RI } \\
\text { SLAC } \\
\text { UCSAN }\end{array}$ & $\begin{array}{l}\text { Lawrence Berkeley Laboratory } \\
\text { Laboratory for Energy-Related Health Research, } \\
\text { Lawrence Livermore National Laboratory } \\
\text { Lawrence Livermore Explosive Test Site } \\
\text { Rockwell International. Santa Susana Field Lab. } \\
\text { Stanford Linear Accelerator Center } \\
\text { Laboratory of Radiobiology and Environmental Healt } \\
\text { University of California. San Francisco }\end{array}$ & $\begin{array}{l}\text { Berkeley, CA } \\
\text { Davis, CA ( } 8) \\
\text { Livermore, CA } \\
\text { Livermore, CA } \\
\text { Canoga Park, CA } \\
\text { Stanford. CA } \\
\text { th, } \\
\text { San Francisco, CA }\end{array}$ \\
\hline PETC & PETC & Pittsburgh Energy Technology Center & Pittsburgh, PA (1) \\
\hline Richland (RL) & HANF & Hanford Site & Richland, WA \\
\hline $\begin{array}{l}\text { Rocky Flats } \\
\text { (RFO) }\end{array}$ & RFP & Rocky Flats Plant & Goiden, CO \\
\hline Savannah River & SRS & Savannah River Site & Aiken, SC \\
\hline
\end{tabular}

(SR) 
Table 1. U.S. Department of Energy Sites by Operations Office and Location (Cont inued)

DOE

Operations

Site

office

Abbreviation Site Name

Site Location

U.S. DOE Remedial Action, Storage, and Disposal Sites

$\begin{array}{llll}\text { Oak Ridge } & \text { CISS } & \text { Colonie Interim Storage Site } & \text { Colonie, NY } \\ \text { (OR) } & \text { HISS } & \text { Hazelwood Interim Storage Site } & \text { Hazelwood, MO } \\ & \text { MISS } & \text { Maywood Interim Storage Site } & \text { Maywood, NJ } \\ & \text { MSP } & \text { Middlesex Sampling Plant } & \text { Middlesex, NJ } \\ & \text { NBS } & \text { New Brunswick Site } & \text { New Brunswick, NJ } \\ & \text { NFSS } & \text { Niagara Falls Storage Site } & \text { Lewiston, NY } \\ & \text { WISS } & \text { Wayne Interim Storage Site } & \text { Wayne, NJ } \\ & \text { WSSRAP } & \text { Weldon Springs Site Remedial Action Project } & \text { Weldon Springs, MO }\end{array}$

(1) This site did not report any radionuclide emissions during the previous calendar year and is not included in subsequent tables.

(2) DOE facilities at this site have been decommissioned, and it is no longer required to report under Subpart $H$ of 40 CFR 61 . It will not be included in subsequent annual surmary reports.

(3) Formerly the Feed Materials Production Center (FMPC).

(4) Formerly the Solar Energy Research Institute (SERI).

(5) Naval Reactors is not an operations office; it is an internal component reporting to the Department of Energy Office of Nuclear Energy Programs.

(6) RMI currently reports to the Chicago Operations Office

(7) Formerly the San Francisco Operations Office (SF).

(8) Formerly operated by the University of California at Davis (UCDAV). 
Table 2. Summary of Airborne Radionuclide Releases from Normal Operations at Department of Energy Facilities During Calendar Year 1993

Radionuclide Releases (Ci) (1)

$\begin{array}{llll}\text { DOE } & & \text { Noble } \\ \text { Office Site } & \text { Tritium } & \begin{array}{c}\text { Trans- } \\ \text { Gas }\end{array} & \text { ull } \\ \text { uranic } & \text { Other } & \text { Total }\end{array}$

U.S. DOE Production Sites and Research Facilities

\begin{tabular}{|c|c|c|c|c|c|c|}
\hline $\mathrm{AL}$ & $\begin{array}{l}\text { GJPO } \\
\text { ITRI } \\
\text { LANL } \\
\text { MLM } \\
\text { PANX } \\
\text { PIN } \\
\text { SNLA } \\
\text { SNLA-TTR } \\
\text { SNLL }\end{array}$ & $\begin{array}{l}3.0 \mathrm{E}-10 \\
1.5 \mathrm{E}-06 \\
1.7 \mathrm{E}+03 \\
6.6 \mathrm{E}+02 \\
3.1 \mathrm{E}-01 \\
1.2 \mathrm{E}+02 \\
7.0 \mathrm{E}-05\end{array}$ & $\begin{array}{c}- \\
6.9 \bar{E}-02 \\
1.8 \overline{8}+02 \\
- \\
- \\
1.9 \bar{E}+01 \\
4.5 \bar{E}+00\end{array}$ & $\begin{array}{c}2.2 E-11 \\
2.0 E-08 \\
4.1 E-05 \\
1.2 E-05 \\
- \\
- \\
1.6 E-11\end{array}$ & $\begin{array}{c}2.3 \mathrm{E}-07 \\
2.5 \mathrm{E}-05 \\
2.3 \mathrm{E}+04 \\
1.2 \mathrm{E}-07 \\
- \\
- \\
1.0 \mathrm{E}+00\end{array}$ & $\begin{array}{l}2.3 E-07 \\
6.9 E-02 \\
2.5 E+04 \\
6.6 E+02 \\
3.1 E-01 \\
1.3 E+02 \\
5.5 E+00\end{array}$ \\
\hline $\mathrm{CH}$ & $\begin{array}{l}\text { ANL } \\
\text { BNL } \\
\text { EML } \\
\text { FERMI } \\
\text { MIT } \\
\text { PPPL }\end{array}$ & $\begin{array}{c}3.5 E+01 \\
6.8 E+01 \\
2.3 E-07 \\
- \\
3.0 E+01\end{array}$ & $\begin{array}{c}2.2 E+01 \\
2.1 E+03 \\
- \\
5.7 E-01 \\
- \\
1.8 E+00\end{array}$ & $\begin{array}{c}2.6 E-05 \\
- \\
1.1 E-06 \\
- \\
- \\
-\end{array}$ & $\begin{array}{l}3.2 E+02 \\
4.1 E+02 \\
6.6 E-06 \\
2.1 E+01 \\
1.7 E+01 \\
1.2 E+00\end{array}$ & $\begin{array}{l}3.7 E+02 \\
2.6 E+03 \\
7.9 E-06 \\
2.2 E+01 \\
1.7 E+01 \\
3.3 E+01\end{array}$ \\
\hline FN & FEMP & - & - & - & 1. $7 \mathrm{E}-04$ & $1.7 \mathrm{E}-04$ \\
\hline $\mathrm{GOL}$ & NREL & - & - & - & 1.7E-03 & $1.7 E-03$ \\
\hline ID & $\begin{array}{l}\text { INEL } \\
\text { WVDP }\end{array}$ & $\begin{array}{l}1.1 E+02 \\
3.2 E-02\end{array}$ & $\begin{array}{c}2.6 E+03 \\
-\end{array}$ & $\begin{array}{l}6.8 E-06 \\
6.7 E-07\end{array}$ & $\begin{array}{l}3.2 E+01 \\
4.1 E-05\end{array}$ & $\begin{array}{l}2.7 E+03 \\
3.2 E-02\end{array}$ \\
\hline NR & $\begin{array}{l}\text { BET } \\
\text { KAPL-1 } \\
\text { KAPL-2 } \\
\text { KAPL-3 }\end{array}$ & $\begin{array}{l}- \\
\text { - } \\
\text { - }\end{array}$ & $\begin{array}{c}- \\
7.3 E-01 \\
1.4 E+00 \\
3.3 E-02\end{array}$ & $\begin{array}{c}9.6 E-09 \\
2.5 E-07 \\
- \\
-\end{array}$ & $\begin{array}{c}1.1 E-05 \\
1.3 E-05 \\
- \\
-\end{array}$ & $\begin{array}{l}1.1 E-05 \\
7.3 E-01 \\
1.4 E+00 \\
3.3 E-02\end{array}$ \\
\hline NV & NTS & $7.1 E+02$ & 1. $6 E+02$ & $1.8 E-03$ & 2.0E-06 & $8.7 E+02$ \\
\hline $\mathrm{OR}$ & $\begin{array}{l}\text { ORR } \\
\text { PAD } \\
\text { PORT }\end{array}$ & $\begin{array}{c}2.4 E+02 \\
- \\
-\end{array}$ & $\begin{array}{c}1.9 E+03 \\
- \\
-\end{array}$ & $\begin{array}{c}2.2 E-03 \\
4.9 E-06 \\
-\end{array}$ & $\begin{array}{l}7.5 \mathrm{E}+01 \\
4.5 \mathrm{E}-03 \\
7.8 \mathrm{E}+00\end{array}$ & $\begin{array}{l}2.2 E+03 \\
4.5 E-03 \\
7.8 E+00\end{array}$ \\
\hline OAK & $\begin{array}{l}\text { LBL } \\
\text { LEHR } \\
\text { LLNL } \\
\text { LLNL-300 } \\
\text { RI } \\
\text { SLAC } \\
\text { UCSAN }\end{array}$ & $\begin{array}{c}1.0 \mathrm{E}+02 \\
4.8 \mathrm{E}-06 \\
2.4 \mathrm{E}+02 \\
3.6 \mathrm{E}-02 \\
1.5 \mathrm{E}-04 \\
- \\
-\end{array}$ & $\begin{array}{c}1.0 E-01 \\
- \\
- \\
- \\
- \\
1.7 E-01 \\
-\end{array}$ & $\begin{array}{c}3.6 E-08 \\
5.4 E-11 \\
4.7 E-07 \\
- \\
6.1 E-09 \\
- \\
-\end{array}$ & $\begin{array}{c}8.7 E+00 \\
5.5 E-05 \\
7.5 E+00 \\
- \\
7.7 E-07 \\
1.9 E+00 \\
3.1 E-05\end{array}$ & $\begin{array}{l}1.1 E+02 \\
6.0 E-05 \\
2.5 E+02 \\
3.6 E-02 \\
1.5 E-04 \\
2.1 E+00 \\
3.1 E-05\end{array}$ \\
\hline RL & HANF & 1. $3 E+01$ & - & $4.1 E-03$ & $8.2 E-03$ & $1.3 E+01$ \\
\hline RFO & RFP & $3.7 E-03$ & - & $3.2 E-07$ & $1.8 \mathrm{E}-06$ & $3.7 E-03$ \\
\hline SR & SRS & $1.9 E+05$ & $3.2 E-02$ & $2.5 E-03$ & $2 . F_{1} E-02$ & 1. $9 E+05$ \\
\hline
\end{tabular}

U.S. DOE Renedial Action, Storage, and Disposal Sites

\begin{tabular}{lllllll} 
OR CISS & $0.0 \mathrm{E}+00$ & $0.0 \mathrm{E}+00$ & $0.0 \mathrm{E}+00$ & $4.6 \mathrm{E}-06$ & $4.6 \mathrm{E}-06$ \\
Total & $2.0 \mathrm{E}+05$ & $6.8 \mathrm{E}+03$ & $8.9 \mathrm{E}-03$ & $2.4 \mathrm{E}+04$ & $2.3 \mathrm{E}+05$ \\
\hline
\end{tabular}

(1) To convert values in this table to SI units. use the conversion factor: $1 \mathrm{Ci}=3.7 \times 10^{10} \mathrm{~Bq}$.

(2) Estimates for this site include emissions from diffuse sources.

(3) Estimates for this site include unplanned releases. 
Table 3. Dose to the Maximally Exposed Offsite Individual from Radionuclide Emissions to Air at Department of Energy Sites During Calendar Year 1993 - Normal Operations (1)

\begin{tabular}{|c|c|c|c|c|c|}
\hline $\begin{array}{l}\text { DOE } \\
\text { Office }\end{array}$ & Site & $\begin{array}{l}\text { Maximum } \\
\text { Offsite } \\
\text { EDE (mrem) }\end{array}$ & $\begin{array}{l}\text { Receptor } \\
\text { Distance (2) } \\
\text { (meters) }\end{array}$ & $\begin{array}{c}\text { Compl iance } \\
\text { Code }\end{array}$ & Notes \\
\hline AL & $\begin{array}{l}\text { GJPO } \\
\text { ITRI } \\
\text { LANL } \\
\text { MLM } \\
\text { PANX } \\
\text { PIN } \\
\text { SNLA } \\
\text { SNLA-TTR } \\
\text { SNLL }\end{array}$ & $\begin{array}{c}6.0 \mathrm{E}-05 \\
3.2 \mathrm{E}-06 \\
5.6 \mathrm{E}+00 \\
4.0 \mathrm{E}-02 \\
5.7 \mathrm{E}-05 \\
2.3 \mathrm{E}-03 \\
1.6 \mathrm{E}-03 \\
\text { TBD } \\
2.6 \mathrm{E}-02\end{array}$ & $\begin{array}{r}400 \\
1360 \\
800 \\
800 \\
800 \\
620 \\
1610 \\
2744 \\
1100\end{array}$ & $\begin{array}{r}\text { CAP88-PC } \\
\text { CAP88-PC } \\
\text { CAP-88 } \\
\text { CAP-88 } \\
\text { CAP88-PC } \\
\text { CAP88-PC } \\
\text { CAP88-PC } \\
\text { CAP88-PC } \\
\text { CAP88-PC }\end{array}$ & $\begin{array}{l}(3) \\
(3) \\
(3) \\
(3)\end{array}$ \\
\hline $\mathrm{CH}$ & $\begin{array}{l}\text { ANL } \\
\text { BNL } \\
\text { EML } \\
\text { FERMI } \\
\text { MIT } \\
\text { PPPL }\end{array}$ & $\begin{array}{l}1.4 \mathrm{E}-02 \\
1.9 \mathrm{E}-01 \\
4.2 \mathrm{E}-02 \\
6.5 \mathrm{E}-03 \\
2.7 \mathrm{E}-02 \\
2.7 \mathrm{E}-02\end{array}$ & $\begin{array}{r}1000 \\
1500 \\
44 \\
800 \\
300 \\
351\end{array}$ & $\begin{array}{r}\text { CAP-88 } \\
\text { CAP-88 } \\
\text { COMPLY Level } 4 \\
\text { CAP88-PC } \\
\text { COMPLY Level } 2 \\
\text { COMPLY Level } 4\end{array}$ & (3) \\
\hline FN & FEMP & $6.6 \mathrm{E}-03$ & 1081 & CAP88-PC & \\
\hline GOL & NREL & $1.7 \mathrm{E}-03$ & 275 & COMPLY Level 4 & \\
\hline ID & $\begin{array}{l}\text { INEL } \\
\text { WVDP }\end{array}$ & $\begin{array}{l}1.1 \mathrm{E}-02 \\
2.0 \mathrm{E}-04\end{array}$ & $\begin{array}{r}20300 \\
1900\end{array}$ & $\begin{array}{r}\text { CAP-88 } \\
\text { CAP88-PC }\end{array}$ & (4) \\
\hline NR & $\begin{array}{l}\text { BET } \\
\text { KAPL-1 } \\
\text { KAPL-2 } \\
\text { KAPL-3 }\end{array}$ & $\begin{array}{l}1.3 \mathrm{E}-03 \\
2.1 \mathrm{E}-03 \\
1.7 \mathrm{E}-02 \\
1.2 \mathrm{E}-03\end{array}$ & $\begin{array}{r}238 \\
500 \\
1400 \\
700\end{array}$ & $\begin{array}{r}\text { CAP88-PC } \\
\text { CAP-88 } \\
\text { CAP-88 } \\
\text { CAP-88 }\end{array}$ & (5) \\
\hline NV & NTS & $3.8 \mathrm{E}-03$ & 80000 & CAP88-PC & (3) \\
\hline OR & $\begin{array}{l}\text { ORR } \\
\text { PAD } \\
\text { PORT }\end{array}$ & $\begin{array}{l}1.4 E+00 \\
2.3 E-03 \\
9.1 E-01\end{array}$ & $\begin{array}{l}1080 \\
2401 \\
1770\end{array}$ & $\begin{array}{l}\text { CAP-88 } \\
\text { CAP-88 } \\
\text { CAP-88 }\end{array}$ & $\begin{array}{l}\text { (6) } \\
(6)\end{array}$ \\
\hline OAK & $\begin{array}{l}\text { LBL } \\
\text { LEHR } \\
\text { LLNL } \\
\text { LLNL-300 } \\
\text { RI } \\
\text { SLAC } \\
\text { UCSAN }\end{array}$ & $\begin{array}{l}1.3 E-01 \\
3.2 E-03 \\
4.0 E-02 \\
1.1 E-02 \\
1.1 E-06 \\
9.3 E-03 \\
9.3 E-05\end{array}$ & $\begin{array}{r}110 \\
75 \\
948 \\
2380 \\
2867 \\
400 \\
200\end{array}$ & $\begin{array}{l}\text { CAP88-PC } \\
\text { CAP88-PC } \\
\text { CAP88-PC } \\
\text { CAP88-PC } \\
\text { CAP88-PC } \\
\text { CAP88-PC } \\
\text { CAP88-PC }\end{array}$ & $(3,6)$ \\
\hline RL & HANF & $6.3 E-03$ & 1500 & CAP88-PC & \\
\hline RFO & RFP & $1.6 \mathrm{E}-03$ & 3942 & CAP88-PC & (3) \\
\hline SR & SRS & $1.8 E-01$ & 16100 & CAP-88 & $(3,6)$ \\
\hline
\end{tabular}

(1) Dose estimates include point sources only unless otherwise indicated.

(2) Receptor distance represents distance from the maximally exposed member of the public to the facility which is the major contributor to dose, or to a central reference point for site.

(3) Estimates for this site include emissions from diffuse sources.

(4) The reported dose is a sum of EDE estimates for maximum individual receptors associated with each facility; the maximum combined dose at a single offsite location was not estimated.

(5) The reported compliance dose is the maximum dose calculated for any direction at the receptor's distance from the source. The actual dose to the maximally exposed individual may be lower than the reported dose.

(6) Estimates for this site include unplanned releases. 
Table 4. Summary of Airborne Radionuclide Releases from Sources Other than Normal Operations at Department of Energy Facilities During Calendar Year 1993 (1)

Diffuse Source Radionuclide Emissions (Ci)

U.S. Department of Energy Production Sites and Research Laboratories

\begin{tabular}{|c|c|c|c|c|c|c|}
\hline $\begin{array}{l}\text { DOE } \\
\text { Office }\end{array}$ & Site & Tritium & $\begin{array}{c}\text { Noble } \\
\text { Gas }\end{array}$ & $\begin{array}{l}\text { Trans- } \\
\text { uranic }\end{array}$ & $\begin{array}{c}\text { A11 } \\
\text { Other }\end{array}$ & Total \\
\hline AL & $\begin{array}{l}\text { GJPO } \\
\text { LANL } \\
\text { MLM } \\
\text { PANX } \\
\text { SNLA } \\
\text { SNLA-TTR }\end{array}$ & $\begin{array}{c}-\overline{1} \\
1.5 \bar{E}+01 \\
-\bar{E} \\
3.1 \mathrm{E}-01 \\
2.9 \mathrm{E}-01\end{array}$ & $\begin{array}{c}- \\
2.0 \bar{E}+02 \\
- \\
- \\
-\end{array}$ & $\begin{array}{c}- \\
1.3 \bar{E}-05 \\
1.1 \mathrm{E}-04 \\
- \\
-\end{array}$ & $\begin{array}{c}2.6 E-06 \\
1.2 E+03 \\
- \\
- \\
-\end{array}$ & $\begin{array}{c}2.6 E-06 \\
1.4 E+03 \\
1.1 E-04 \\
3.1 E-01 \\
2.9 E-01 \\
\text { TBD }\end{array}$ \\
\hline $\mathrm{CH}$ & BNL & $3.3 E-03$ & $2.9 E+00$ & - & $6.3 E+02$ & $6.3 \mathrm{E}+02$ \\
\hline FN & FEMP & - & - & - & $2.8 \mathrm{E}-04$ & $2.8 E-04$ \\
\hline ID & $\begin{array}{l}\text { INEL } \\
\text { WVDP }\end{array}$ & $\begin{array}{l}1.3 E+02 \\
1.5 E-01\end{array}$ & - & $\begin{array}{l}3.4 \mathrm{E}-05 \\
9.6 \mathrm{E}-07\end{array}$ & $\begin{array}{l}1.5 \mathrm{E}-03 \\
1.7 \mathrm{E}-03\end{array}$ & $\begin{array}{l}\text { 1. } .3 E+02 \\
1.5 E-01\end{array}$ \\
\hline NR & $\begin{array}{l}\text { KAPL-1 } \\
\text { KAPL-2 }\end{array}$ & - & - & - & - & - \\
\hline NV & NTS & $7.0 \mathrm{E}+02$ & $1.6 \mathrm{E}+02$ & $1.8 \mathrm{E}-03$ & - & $8.6 E+02$ \\
\hline OR & ORR & $1.2 \mathrm{E}+01$ & - & - & - & 1. $2 E+01$ \\
\hline OAK & $\begin{array}{l}\text { LBL } \\
\text { LEHR } \\
\text { LLNL } \\
\text { LLNL-300 } \\
\text { RI }\end{array}$ & $\begin{array}{c}6.0 E-02 \\
6.7 E-04 \\
5.2 E+00 \\
1.2 E+00 \\
-\end{array}$ & $\begin{array}{l}- \\
- \\
- \\
-\end{array}$ & $\begin{array}{l}- \\
- \\
(5) \\
- \\
-\end{array}$ & $\begin{array}{c}2 . \\
2.8 E-04 \\
(5) \\
(5) \\
1.1 E-05\end{array}$ & $\begin{array}{l}6.0 E-02 \\
9.5 E-04 \\
5.2 E+00 \\
1.2 E+00 \\
1.1 E-05\end{array}$ \\
\hline RL & HANF & - & - & $1.1 \mathrm{E}-03$ & $1.0 E+00$ & 1. $.0 E+00$ \\
\hline RFO & RFO & - & - & 4. $0 E-05$ & $1.3 E-06$ & $4.1 E-05$ \\
\hline$S R$ & SRS & $4.3 E+01$ & - & $3.2 E-07$ & $1.1 E-04$ & $4.3 E+01$ \\
\hline Total & & $9.1 E+02$ & $3.6 E+02$ & $3.1 E-03$ & $1.8 \mathrm{E}+03$ & $3.1 E+03$ \\
\hline
\end{tabular}

U.S. Department of Energy Remedial Action, Storage, and Disposal Sites

\begin{tabular}{|c|c|c|c|c|c|c|}
\hline OR & CISS & - & - & - & $2.4 E-05$ & $2.4 E-05(6)$ \\
\hline & HISS & - & - & - & $8.1 E-05$ & $8.1 E-05$ \\
\hline & MISS & - & - & - & $6.5 E-05$ & $6.5 E-05$ \\
\hline & MSP & - & - & - & $1.5 \mathrm{E}-06$ & $1.5 E-06$ \\
\hline & NBS & - & - & - & $4.2 E-06$ & $4.2 E-06$ \\
\hline & NFSS & - & - & - & $1.1 \mathrm{E}-07$ & 1.1E-07 \\
\hline & WISS & - & - & - & $7.2 E-07$ & $7.2 E-07$ \\
\hline & WSSRAP & - & - & - & - & $-\quad(5)$ \\
\hline Total & & - & - & - & $2.2 E-04$ & 2.2E-04 \\
\hline
\end{tabular}


Table 4. Summary of Airborne Radionuclide Releases from Sources Other than (cont.) Normal Operations at Department of Energy Facilities During Calendar Year 1993

Unplanned Radionuclide Emissions (Ci)

DOE

Office Site

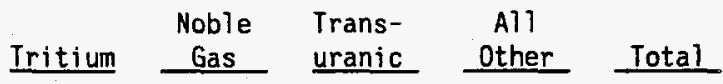

U.S. Department of Energy Production Sites and Research Laboratories

\begin{tabular}{|c|c|c|c|c|c|c|c|}
\hline$A L$ & $\begin{array}{l}\text { LANL } \\
\text { PIN }\end{array}$ & $\begin{array}{c}3.5 E+01 \\
-\end{array}$ & $9 . \bar{E}+00$ & & - & $\begin{array}{l}\text { (7) } \\
-\end{array}$ & $\begin{array}{l}3.5 E+01 \\
9.3 E+00\end{array}$ \\
\hline $\mathrm{CH}$ & PPPL & $1.1 E+01$ & - & & - & - & 1. $1 \mathrm{E}+01$ \\
\hline OR & $\begin{array}{l}\text { ORR } \\
\text { PAD } \\
\text { PORT }\end{array}$ & $\begin{array}{l}- \\
-\end{array}$ & $\begin{array}{l}- \\
-\end{array}$ & & - & $\begin{array}{c}- \\
7.8 \mathrm{E}+00\end{array}$ & $\begin{array}{c}- \\
7.8 \mathrm{E}+00\end{array}$ \\
\hline OAK & $\begin{array}{l}\text { LBL } \\
\text { LLNL }\end{array}$ & $\begin{array}{c}4.4 E+01 \\
-\end{array}$ & $1 . \overline{6 E}+01$ & (9) & - & - & $\begin{array}{l}4.4 E+01 \\
1.6 E+01\end{array}$ \\
\hline SR & SRS & $9.7 \mathrm{E}+00$ & - & \multicolumn{2}{|c|}{$2.1 E-04$} & - & $9.7 E+00$ \\
\hline Tota & & $1.0 E+02$ & $2.5 \mathrm{E}+01$ & \multicolumn{2}{|c|}{$2.1 E-04$} & $7.8 E+00$ & $1.3 \mathrm{E}+02$ \\
\hline
\end{tabular}

(1) To convert values in this table to SI units, use the conversion factor: $1 \mathrm{Ci}=3.7 \times 10^{10} \mathrm{~Bq}$

(2) Diffuse source emissions do not include radon, except as noted.

(3) Part or all of these emissions were included in the site's normal operation releases.

(4) Dose from contaminated soil area is calculated, but release estimates not reported for some or all radionuclides.

(5) Radionuclide releases were not estimated because dose was calculated directly from measured air concentrations.

(6) Release estimates for this site include resuspension from contaminated soil areas and emissions from a support services building located at the site.

(7) An unplanned release of depleted uranium was reported, but the composition was not specified.

(8) An unplanned release of uranium hexafluoride was reported, but the total activity was not specified.

(9) Also reported as a $\mathrm{Rn}-220$ release. 
Table 5. Summary of Airborne Radon Releases from Department of Energy Facilities During Calendar Year 1993. (1)

\begin{tabular}{|c|c|c|c|c|}
\hline \multirow{2}{*}{$\begin{array}{l}D O E \\
\text { Office } \\
\end{array}$} & \multirow[b]{2}{*}{ Site } & \multicolumn{3}{|c|}{ Radon Releases (Ci) } \\
\hline & & $R n-220$ & $R n-222$ & Total \\
\hline AL & $\begin{array}{l}\text { ITRI } \\
\text { MLM }\end{array}$ & $8.8 E-02$ & $\begin{array}{l}3.0 E-03 \\
1.1 E+00\end{array}$ & $\begin{array}{r}9.1 \mathrm{E}-02 \\
1.1 \mathrm{E}+00\end{array}$ \\
\hline $\mathrm{CH}$ & ANL & $2.0 E+03$ & - & $2.0 E+03$ \\
\hline NR & BET & $6.5 E+02$ & $9.8 \mathrm{E}-01$ & $6.5 \mathrm{E}+02$ \\
\hline OAK & LLNL & $1.6 \mathrm{E}+01 \quad(2)$ & $5.9 E-05$ & $1.6 \mathrm{E}+01$ \\
\hline RL & HANF & $9.7 E+01$ & $1.5 E+00$ & $9.8 \mathrm{E}+01$ \\
\hline Total & & $2.8 \mathrm{E}+03$ & $3.6 \mathrm{E}+00$ & $2.8 \mathrm{E}+03$ \\
\hline
\end{tabular}

U.S. Department of Energy Remedial Action, Storage, and Disposal Sites

\begin{tabular}{|c|c|c|c|c|c|c|}
\hline \multirow[b]{2}{*}{ Site } & \multicolumn{3}{|c|}{$\begin{array}{l}\text { Radon-222 } \\
(\mathrm{pCi} / \mathrm{L})\end{array}$} & \multicolumn{3}{|c|}{$\begin{array}{c}\text { Radon-220 } \\
(\mathrm{pCi} / \mathrm{L})\end{array}$} \\
\hline & Minimum & Maximum & Average & Minimum & Maximum & Average \\
\hline HISS & 0.3 & 0.8 & 0.5 & - & - & - \\
\hline MISS & $<0.3$ & 2.1 & 0.4 & $<0.3$ & 11.4 & 1.4 \\
\hline MSP & $<0.3$ & 0.6 & 0.4 & $<0.3$ & $<0.3$ & $<0.3$ \\
\hline NBS & $<0.3$ & 1.5 & $0.4(4)$ & - & - & - \\
\hline NFSS & $<0.3$ & 0.6 & 0.4 & - & - & - \\
\hline WISS & $<0.3$ & 0.4 & 0.3 & $<0.3$ & 1.1 & 0.4 \\
\hline WSSRAP & 0.1 & 1.9 & $0.4(5)$ & - & - & - \\
\hline
\end{tabular}

(1) To convert values in this table to SI units, use the conversion factor: $1 \mathrm{Ci}=3.7 \times 10^{10} \mathrm{~Bq}$.

(2) Rn-220 release is also reported as an unplanned release.

(3) These values represent annual or quarterly average concentrations at perimeter sampling stations, not corrected for background. The DOE guideline for $\mathrm{Rn}-222$ and $\mathrm{Rn}-220$ is $3 \mathrm{pCi} / \mathrm{L}$ (in addition to background).

(4) Radon-222 concentrations also include radon-220.

(5) Reported concentrations are for samples at Weldon Springs quarry. Samples from other locations indicated lower concentrations. 
Table 6. Dose to the Maximally Exposed Offsite Individual From Radionuclid Emissions to Air at Department of Energy Sites During Calendar Year 1993 - Sources Other than Normal Operations

Emissions Source

$\begin{array}{llll}\begin{array}{l}\text { DOE } \\ \text { Office }\end{array} \text { Site } & \begin{array}{l}\text { Diffuse } \\ \text { (mrem) }\end{array} & \begin{array}{c}\text { Unplanned } \\ \text { (mrem) }\end{array} & \begin{array}{c}\text { Radon } \\ \text { (mrem) }\end{array} \\ & & & \end{array}$

U.S. Department of Energy Research and Production Sites

$\mathrm{AL}$

GJPO
ITRI
LANL
MLM
PANX
PIN
SNLA
SNLA-TTR

$\mathrm{CH}$

ANL

BNL

PPPL

FN

ID INEL

WVDP

NR

BET

KAPL-1

KAPL-2

NV NTS

OR

ORR

PAD

PORT

OAK

LBL
LEHR
LLNL
LLNL-300
RI

RL HANF

RFP

RFO

RFP

SR SRS
2. $1 E-03$

1. $1 E+00$

2. $2 \mathrm{E}-01$

$5.7 \mathrm{E}-05$

$-$

8.5E-06

1.3E-04<smiles>[I-]</smiles>

$\leq 8.9 \bar{E}-08$

$\leq 8.9 E-08$

$-$

\section{2. $4 \mathrm{E}-01$}

2.1E-05

(2)

1.6E-02

$7.4 E-05$ (3)

1. $0 \mathrm{E}-01$

2.0E-06

$<2.0 \mathrm{E}-07$

3. $8 \mathrm{E}-03$

(2)

$1.0 \mathrm{E}-02$

9. $0 \mathrm{E}-05$

(2)

5. $4 \mathrm{E}-04$

(4)

8. $5 E-02$ (2)

$3.3 \mathrm{E}-05$

(2)

2. $6 \mathrm{E}-02$

2. $6 \mathrm{E}-02$

3. $4 \mathrm{E}-05$

(2)

$3.0 \mathrm{E}-04$

(5)

3. $0 E-04$

(5)

2.7E-01

$2.8 \mathrm{E}-02(6)$

$1.6 \mathrm{E}-03$ (2)

8.0E-05 (2)

2.1E-04

(2) 
Table 6. Dose to the Maximally Exposed Offsite Individual From Radionuclide (cont.) Emissions to Air at Department of Energy Sites During Calendar Year 1993 - Sources Other than Normal Operations

DOE

office Site

Diffuse
(mrem)

Emissions Source

\begin{tabular}{cc}
$\begin{array}{c}\text { Unplanned } \\
\text { (mrem) }\end{array}$ & $\begin{array}{c}\text { Radon } \\
\text { (mrem) }\end{array}$ \\
\hline
\end{tabular}

(1)

\section{U.S. Department of Energy Storage and Disposal Sites}

$\begin{array}{cl}\text { OR CISS } & 4.5 \mathrm{E}-02(7) \\ \text { HISS } & 1.0 \mathrm{E}+00(8) \\ \text { MISS } & 4.6 \mathrm{E}-01 \\ \text { MSP } & 3.9 \mathrm{E}-03 \\ \text { NBS } & 6.8 \mathrm{E}-02 \\ \text { NFSS } & 1.7 \mathrm{E}-06 \\ \text { WISS } & 1.9 \mathrm{E}-02 \\ \text { WSSRAP } & 3.8 \mathrm{E}-01\end{array}$

(1) Doses from diffuse emissions do not include $R n-220$ and $R n-222$, except as noted.

(2) Part or all of these estimates were included in the site's compliance dose.

(3) Reported dose is the sum of EDE estimates for maximum individual receptors associated with each facility: the maximum combined dose at a single offsite location was not estimated.

(4) Dose for unplanned release was not reported separately. The site report does not indicate whether this dose was included in the site compliance dose.

(5) Radon dose is included in the dose from unplanned emissions.

(6) This dose estimate is for the location that corresponds to the maximally exposed individual from point source emissions. The corresponding maximum dose at the site perimeter from diffuse sources only was at a different location, and amounted to $4.9 \mathrm{E}-02$ mrem. Both estimates may include contributions from naturally occurring radionuclides or emissions from non-DOE sources.

(7) The estimated dose includes both contaminated soil sources and emissions from a support building located at the site.

(8) CAP88-PC dase estimate for this site is adjusted using an occupancy factor where the maximally exposed individual is not a full-time resident. 
Table 7. Collective Dose to the $80-\mathrm{km}$ Population From Radionuclide Emissions to Air at Department of Energy Sites During Calendar Year 1993

$\begin{array}{lll}\text { DOE } & \begin{array}{l}\text { Collective Dose } \\ \text { Office Site }\end{array} & \begin{array}{l}\text { Population } \\ \text { within } 80 \mathrm{~km}\end{array}\end{array}$

U.S. DOE Production Sites and Research Facilities

\begin{tabular}{|c|c|c|c|}
\hline AL & $\begin{array}{l}\text { GJPO } \\
\text { ITRI } \\
\text { LANL } \\
\text { MLM } \\
\text { PANX } \\
\text { PIN } \\
\text { SNLA } \\
\text { SNLL }\end{array}$ & $\begin{array}{l}9.9 \mathrm{E}-02 \\
5.5 \mathrm{E}-05 \\
3.0 \mathrm{E}+00 \\
2.1 \mathrm{E}+00 \\
1.0 \mathrm{E}-04 \\
4.3 \mathrm{E}-02 \\
2.6 \mathrm{E}-02 \\
1.4 \mathrm{E}+00\end{array}$ & $\begin{array}{l}1.0 \mathrm{E}+05 \text { (1) } \\
5.0 \mathrm{E}+05 \\
2.1 \mathrm{E}+05 \\
3.0 \mathrm{E}+06 \\
2.8 \mathrm{E}+05 \\
2.5 \mathrm{E}+06 \\
5.7 \mathrm{E}+05 \\
6.0 \mathrm{E}+06\end{array}$ \\
\hline $\mathrm{CH}$ & $\begin{array}{l}\text { ANL } \\
\text { BNL } \\
\text { FERMI } \\
\text { PPPL }\end{array}$ & $\begin{array}{l}1.3 E+01 \\
4.7 E+00 \\
1.5 E-02 \\
9.9 E-01\end{array}$ & $\begin{array}{l}7.9 E+06(1) \\
5.0 E+06(1,2) \\
7.8 E+06 \\
5.0 E+06\end{array}$ \\
\hline FN & FEMP & $2.9 E-01$ & $2.7 E+06$ (1) \\
\hline GOL & NREL & $\geq 1.0 \mathrm{E}+00$ & $1.8 \mathrm{E}+06$ \\
\hline ID & $\begin{array}{l}\text { INEL } \\
\text { WVDP }\end{array}$ & $\begin{array}{l}\text { 3. } 0 E-01 \\
2.7 E-03\end{array}$ & $\begin{array}{c}1.2 E+05 \\
-\end{array}$ \\
\hline NR & $\begin{array}{l}\text { BET } \\
\text { KAPL-1 } \\
\text { KAPL-2 } \\
\text { KAPL-3 }\end{array}$ & $\begin{array}{l}3.0 E+00 \\
3.4 E-03 \\
4.1 E-02 \\
5.0 E-04\end{array}$ & $\begin{array}{l}3.2 E+06(1) \\
1.3 E+06 \\
1.2 E+06 \\
3.4 E+06\end{array}$ \\
\hline NV & NTS & $1.2 E-02$ & $2.2 E+04$ \\
\hline OR & $\begin{array}{l}\text { ORR } \\
\text { PAD } \\
\text { PORT }\end{array}$ & $\begin{array}{l}2.6 E+01 \\
1.1 E-02 \\
1.2 E+01\end{array}$ & $\begin{array}{l}9.4 E+05 \\
5.4 E+05 \\
6.0 E+05\end{array}$ \\
\hline OAK & $\begin{array}{l}\text { LBL } \\
\text { LEHR } \\
\text { LLNL } \\
\text { LLNL-300 } \\
\text { RI } \\
\text { SLAC } \\
\text { UCSAN }\end{array}$ & $\begin{array}{l}1.3 E+00 \\
6.8 E-01 \\
9.8 E-01 \\
6.9 E+00 \\
2.4 E-03 \\
1.2 E-02 \\
2.1 E-05\end{array}$ & $\begin{array}{r}5.1 E+06 \quad(2) \\
-5.0 E+06 \\
6.3 E+06 \quad(1) \\
5.4 E+06(1) \\
9.4 E+06 \\
-6.0 E+06 \quad(4) \\
\sim 6.0 E+06\end{array}$ \\
\hline RL & HANF & $3.0 \mathrm{E}-01$ & $3.8 E+05$ \\
\hline RFO & RFP & $1.2 E-01$ & $2.0 E+06 \quad(1)$ \\
\hline$S R$ & SRS & $2.0 E+01$ & $6.2 E+05$ (1) \\
\hline
\end{tabular}

U.S. DOE Remedial Action, Storage, and Disposal Sites

$\begin{array}{llll}\text { OR } & \text { CISS } & 1.2 \mathrm{E}-02 & 1.3 \mathrm{E}+06(1) \\ & \text { HISS } & 1.1 \mathrm{E}-01 & 2.6 \mathrm{E}+06(1) \\ & \text { MISS } & 3.2 \mathrm{E}-01 & 1.7 \mathrm{E}+07(1) \\ & \text { MSP } & 3.2 \mathrm{E}-03 & 1.7 \mathrm{E}+07(1) \\ & \text { NBS } & 2.5 \mathrm{E}-02 & 1.7 \mathrm{E}+07(1) \\ & \text { NFSS } & 1.5 \mathrm{E}-05 & 4.9 \mathrm{E}+06(1) \\ & \text { WISS } & 2.8 \mathrm{E}-03 & 2.0 \mathrm{E}+07(1) \\ & & & \end{array}$

(1) Dose estimates for these sites include doses from normal operation in addition to other releases such as unplanned releases, radon, or emissions from diffuse sources.

(2) Population data are based on 1980 census.

(3) Collective dose estimate is based on $6 \mathrm{E}-07$ mrem dose to an individual at $80 \mathrm{~km}$.

(4) This dose estimate is for approximately 100,000 people within $6 \mathrm{~km}$ of the site. 